\title{
Economic and environmental analysis of a novel rural house heating and cooling system using a solar-assisted vapour injection heat pump
}

The corrections made in this section will be reviewed and approved by a journal production editor.

[Instruction: * Corresponding author （Xudong Zhao）. Tel.: +44-01482466684, Email:

xudong.zhao@hull.ac.uk ** Corresponding author (Jing Li). Tel.: +44-01482463611, Email:

jing.li@hull.ac.uk]Yi Fan Writing - original draft Formal analysis Methodology Investigation a , Xudong

Zhao Funding acquisition Conceptualization Supervision ${ }^{\text {a }}$, Jing Li Project administration Conceptualization

Supervision a , Guiqiang Li Resources a, Steve Myers Writing - review \& editing a, Yuanda Cheng Software

b, Ali Badiei Writing - review \& editing a , Min Yu Data curation ${ }^{a}$, Yousef Golizadeh Akhlaghi Resources ${ }^{\text {a }}$ Samson Shittu Validation ${ }^{\text {a }}$, Xiaoli Ma Writing - review \& editing ${ }^{\text {a }}$

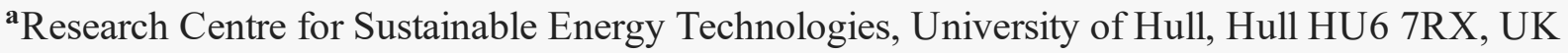

${ }^{\mathbf{b}}$ College of Environmental Science and Engineering, Taiyuan University of Technology, 030024, China

\begin{abstract}
An efficient low-carbon system is proposed to meet the heating and cooling demands of rural houses in cold regions. Mini-channel solar panels incorporating a novel multiple-throughout-flowing loop are used for heat collection, whilst a vapour injection air source heat pump (VI-ASHP) is innovatively combined with an underfloor heating and cooling system. To demonstrate the system, a multiplethroughout-flowing mini-channel solar thermal panel array of $36 \mathrm{~m}^{2}$ and a VI-ASHP of $40 \mathrm{~kW}$ heating capacity have been built and tested. Subsequently, mathematical models of the solar-assisted VI-ASHP system are established and compared with the experimental data. Based on the validated models, the energetic, economic and environmental performance is investigated under the typical weather conditions for a northern Chinese city (Taiyuan). The results indicate that, for a common rural house employing the proposed novel system, the proportion of the annual heat requirement, cooling load and hot water heating energy provided by solar thermal energy, photovoltaic energy and electricity from the power grid is $74.6 \%, 6.9 \%$, and $18.5 \%$ respectively, thus giving a total energy supply proportion of $81.5 \%$ from solar energy. In addition, compared with a coal-powered system, our system has a cost payback period of 6.52 years and a life-cycle net cost saving of 56328.4RMB, thus the proposed system provides a greater economic performance. Furthermore, it can save 5 tons of anthracite coal and reduce carbon emissions by 12.1 tons annually. The proposed solar-assisted VI-
\end{abstract}


ASHP has the potential to fulfil heating and cooling demands whilst reducing carbon emissions in northern China.

Keywords: Solar energy; Mini-channel collector; Vapour injection air source heat pump; Underfloor heating and cooling; Carbon emission; Payback period

\section{Nomenclature}

\begin{tabular}{|c|c|}
\hline$A_{s t}$ & Area of the solar thermal panels, $\mathrm{m}^{2}$ \\
\hline$A_{e}$ & Area of a single PV panel, $\mathrm{m}^{2}$ \\
\hline$b$ & Index of the air permeability of outer doors and windows; \\
\hline$C_{c l C}$ & Solar radiation cooling load factor; \\
\hline$C_{z}$ & Comprehensive shielding coefficient of outer window; \\
\hline$C_{w}$ & Correction factor of the outer shielding device; \\
\hline$C_{n}$ & Correction factor of the inner shielding device; \\
\hline$C_{s}$ & Correction factor of the window glass; \\
\hline$C_{\text {people }}$ & Number of people; \\
\hline $\mathrm{C}_{P T}$ & Cost of the solar thermal panel, RMB; \\
\hline $\mathrm{C}_{P V}$ & Cost of the PV panel, RMB); \\
\hline $\mathrm{C}_{H S E U}$ & Cost of the heat storage and exchange unit, RMB; \\
\hline $\mathrm{C}_{H P}$ & Cost of the heat pump, RMB; \\
\hline $\mathrm{C}_{A D D}$ & Additional cost of the system, RMB; \\
\hline$C p$ & Specific heat capacity, $\mathrm{J} /(\mathrm{kg} \cdot \mathrm{K})$; \\
\hline COP & Coefficient of performance for winter heating; \\
\hline$C_{c}$ & Initial capital cost, RMB; \\
\hline$C_{R E}$ & Renewable Heat Incentive (RHI) scheme, RMB; \\
\hline$C_{o}$ & Cost of operation, RMB; \\
\hline$C_{m}$ & Cost of maintenance, RMB; \\
\hline$C S$ & Life-cycle net cost saving, RMB; \\
\hline$D_{J . m a x}$ & Maximum index of the local solar radiation passing a glass in summer, $\mathrm{W} / \mathrm{m}^{2}$; \\
\hline EER & Energy efficiency ratio for summer cooling; \\
\hline$F_{c}$ & Outer window area, $\mathrm{m}^{2}$ \\
\hline$h_{t}$ & Heat transfer rate of the served house envelope, $\mathrm{W} /\left(\mathrm{m}^{2} \cdot \mathrm{K}\right)$; \\
\hline$I$ & Solar thermal radiation, $\mathrm{kW} / \mathrm{m}^{2}$ \\
\hline$L_{\text {air }}$ & Cold air infiltration volume per hour, $\mathrm{m}^{3} / \mathrm{h}$; \\
\hline$L_{0}$ & Cold air infiltration volume per hour per meter, $\mathrm{m}^{3} /(\mathrm{h} \cdot \mathrm{m})$; \\
\hline$l_{0}$ & Length of the outer windows and doors, m; \\
\hline$\dot{m}$ & Mass flow rate of the working fluid $(\mathrm{kg} / \mathrm{s})$; \\
\hline$m_{c . c}$ & Consumed standard coal by a coal-powered heating system, kg; \\
\hline$m_{p}$ & Air contaminations generated by systems, $\mathrm{kg}$; \\
\hline$m_{p u}$ & Air contaminations generated by using per unit fuel, kg; \\
\hline$N$ & Number of the PV panels; \\
\hline NOTC & Nominal operating cell temperature; \\
\hline
\end{tabular}




\begin{tabular}{ll}
$\eta_{c}$ & $\begin{array}{l}\text { Efficiency of a coal-powered heating system; } \\
\tau_{s t}\end{array}$ \\
\hline$\tau_{w y}$ & Solar collectors operation time, $\mathrm{h} ;$ \\
\hline$\tau_{w p}$ & Electricity generation time, $\mathrm{h} ;$ \\
$\rho$ & Operation time of the water pump, $\mathrm{h} ;$ \\
$\emptyset$ & Density, $\mathrm{kg} / \mathrm{m}^{3} ;$ \\
& Clustering coefficient;
\end{tabular}

\section{Subscripts}

Solar-powered system;

Coal-powered system;

West facing;

East facing;

South facing;

North facing;

Air;

Working fluid;

\section{Introduction}

Energy consumption for space heating [1] and hot water [2] accounts for the majority of total building energy consumption in the north of China, and so far most of the rural houses have been using coal as the main energy source for cooking, space heating and hot water supplying. This has caused severe fossil fuel shortage and environmental pollution including a high level of harmful dust, PM2.5 concentration, greenhouse gas, $\mathrm{CO}_{2}$ and harmful gases, i.e. $\mathrm{SO}_{2}$ and $\mathrm{NO}_{\mathrm{x}}$ [3]. The summer in most areas of northern China is hot and an ambient temperature above $30^{\circ} \mathrm{C}$ is common. The demand for cooling in rural houses is growing with the improvements in people's living standards.

The development of solar technology during recent years has brought revolutionary advances to existing energy systems. Recently, the mini-channel solar thermal collector has been widely investigated. The mini-channel is an aluminium tube with a size of about $1-4 \mathrm{~mm}$, which has been used to improve the performance of solar thermal collectors in recent years [4]. Compared to the conventional copper tube flat-plate panels, the smaller interior space of the mini-channels provides a superior performance on many aspects, i.e. higher heat transfer rate and flow velocity, enhanced solar efficiencies [5], lower convective heat loss and lower cost [6]. Li et al. conducted a simulative and experimental study on mini-channel heat pipe under different evaporator temperatures and tilt angles. The useful results were achieved for the system design, optimization, and installation [7]. Deng et al. studied the performance of a solar-powered hot water system with a mini-channel-heat-pipe array, showing that the annual average system efficiency was 58.29\% [8]. As a result, employing a mini-channel solar thermal panel could improve the amount of heat collection and reduce the cost of the system [9]. Notably, there are three desirable characteristics of northern Chinese rural houses for the utilization of solar energy systems: (1) a large flat roof area for the solar panels installation [10]; (2) rich solar resources throughout the year [11]; and (3) high residential density of large energy demand and low network energy loss. As a result, the potential to utilize solar energy systems in rural areas is larger than in urban buildings. Furthermore, solar energy systems can significantly reduce the local air pollution. 
In addition to the solar technology, the air source heat pump (ASHP) is recognized as an energy-saving approach and has been widely used for space heating and hot water supply in central and northern China [12]. However, with a single-stage compression cycle, the conventional ASHP cannot operate efficiently and steadily in low ambient temperatures [13], due to the low coefficient of performance (COP) and frost formation [14]. The drawbacks of conventional ASHPs have been investigated by many researchers $[15,16]$. To further address the problems associated with conventional ASHPs, the vapour injection (VI) technique is attracting increasing interest [17]. Wang et al. investigated a two-stage air-source heat pump with a flash tank cycle to optimise the intermediate pressure with a real-time optimization method that can retain the use of saturated vapor for the injection line [18]. The capacity and COP of the VI compressor are significantly higher compared to that of the conventional compressors, especially at extremely low ambient temperatures [19]. The reason for the performance improvement lies in the enthalpy difference across the evaporator, which is larger with the twostage expansion [19]. In addition to the remarkable improvement in heating mode, VI also provides significant improvements and enhanced cooling capacity when applied to air conditioning systems [20]. The advantages of VI technique have been validated by a commercialised system, elsewhere [21].

When it comes to the integration of the solar and heat pump systems in houses, hydronic radiant heating and cooling systems have become quite mature [22]. The underfloor heating system can be an efficient alternative to other more common forms of heating [23]. It conserves living and working space as it is integrated into the building structure. Furthermore, it can reduce the energy needed for seasonal heating by $18 \%$ [24] and improve the thermal comfort conditions inside the building [25]. Due to a lower exergy destruction by higher supply temperatures, radiant cooling systems enable more gains [26]. In particular, using the radiant cooling systems in northern China can efficiently reduce the condensation on floor surfaces thanks to the low air humidity.

So far, very few studies on the hybrid solar and VI-ASHP systems have been reported. Chen et al. [27] proposed a new direct-expansion solar-assisted VI-ASHP cycle with a sub-cooler for a water heater. The results showed that the new technology provided an average of $14.6 \%$ and $42.9 \%$ improvement in the COP and capacity, compared with the conventional technology. Lu et al. [28] investigated the solar photovoltaic/thermal heat pump system with VI cycle. According to the results, the average $\mathrm{COP}_{\text {th }}$ and $\mathrm{COP}_{\mathrm{PVT}}$ of the PVT-VIASHP system were 3.27 and 3.45 , respectively.

However, previous studies on solar-assisted VI-ASHP were focused on the heating performance, and the tests were conducted on a laboratory scale. The technology demonstration has yet to be implemented. To meet the heating and cooling demands and reduce carbon emissions in rural houses in northern China, this paper proposes a novel solar-assisted heat pump system. Mini-channel solar collectors are used for heat collection and a vapour injection air source heat pump (VI-ASHP) is incorporated with an underfloor heating and cooling system. Moreover, PV panels are employed to provide electricity for the system. An economic and environmental investigation of the system is carried out. The novelty and contributions of the current work include:

(1) It is the first time that mini-channel solar thermal panels have been combined with VI-ASHP, thus forming a novel solar-assisted VI-ASHP system. The proposed system is further incorporated with an underfloor heating and cooling unit to satisfy the residents' annual energy needs.

(2) Not only the heat supply but also cooling performance and hot water supply of the system are simulated. VI-ASHP is attracting increasing interest in cold regions and studies on its performance in heating mode have been conducted. Its potential in underfloor cooling applications is rarely explored.

(3) The demonstrative system is constructed and presented. 18 mini-channel solar panels with a 
combined aperture area of $36 \mathrm{~m}^{2}$ have been demonstrated and tested in the multiple-throughoutflowing connection method in northern China. Unlike conventional solar panels, which are connected either in series or in parallel and normally have one inlet and outlet, the panels here are connected in a novel multiple-throughout-flowing manner. In addition, the demonstrative VIASHP system of heating capacity of about $40 \mathrm{~kW}$ has also been developed in northern China, providing valuable experimental results.

\section{System description}

The schematic of the novel solar-assisted VI-ASHP space heating, cooling and hot water supply system is shown in Fig. 1. The system is designed to meet the energy demand of a $100 \mathrm{~m}^{2}$ rural house in northern China. It is comprised of: (1) one multiple-throughout-flowing panel array with 8 mini-channel solar thermal panels; (2) a dedicated PV panel array which can earn a profit, thus reducing the operational cost and fossil fuel consumption; (3) a heat storage and exchange unit (HSEU) that stores excess solar heat when the collected heat is greater than the heat demand of the building, and discharges heat into the served house when needed; (4) a VIASHP as a heating device in winter to provide space heating when solar energy and stored energy cannot meet the heat demand, and as a cooling device in summer.

\section{Fig. 1}

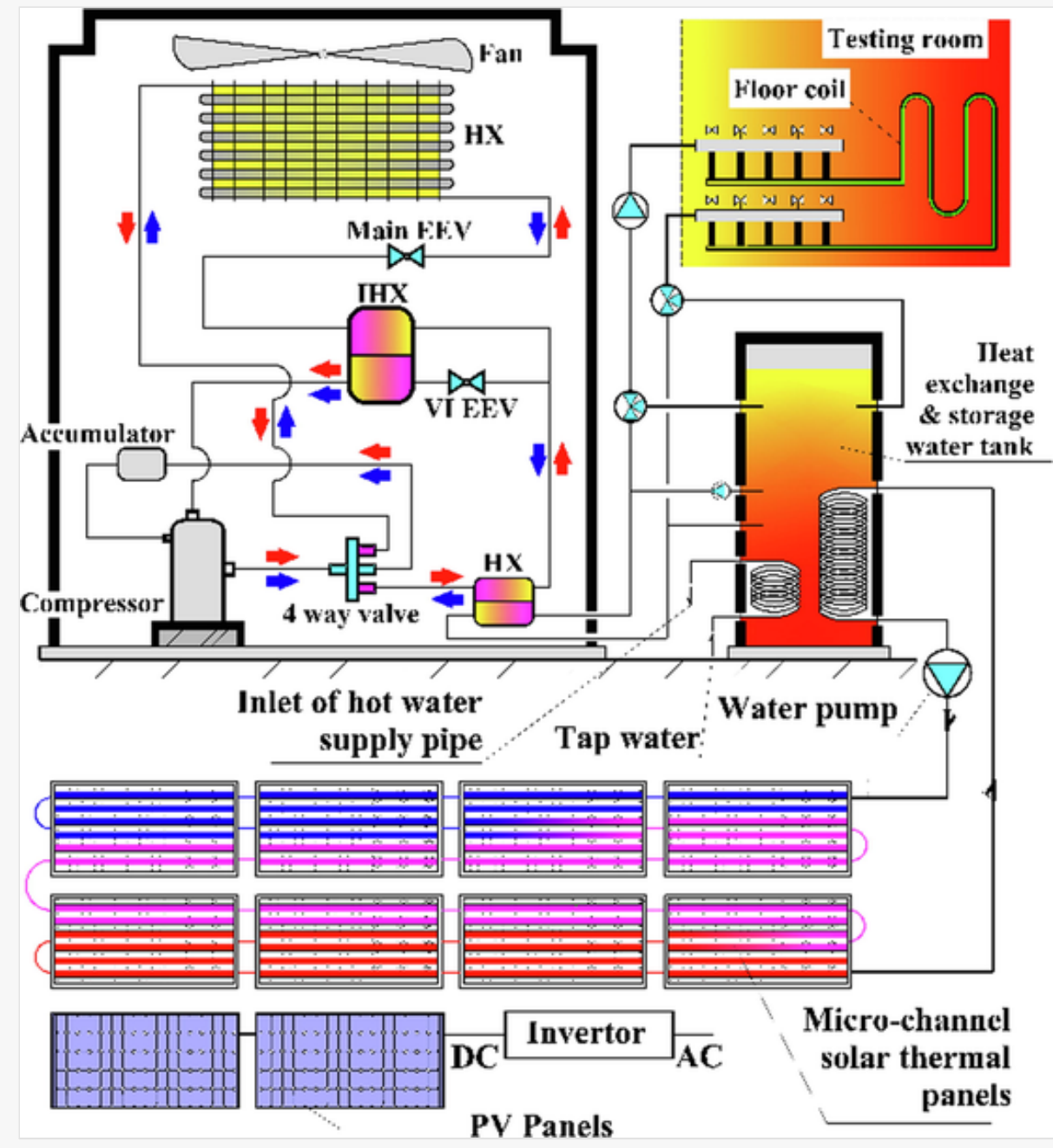

Schematic of the mini-channel solar-powered VI-ASHP system.

The technical specifications of the system's individual components are presented in Table 1. The control scheme of the proposed system for the heating process is divided into three main steps: (1) When the solar loop fluid 
temperature is higher than the water tank temperature, the water pump on the solar loop operates to transfer the collected heat, as shown in Fig. 2(a); (2) When the water tank temperature is higher than $40{ }^{\circ} \mathrm{C}$, it can facilitate space heating, as shown in Fig. 2(b); (3) When the solar energy and the stored energy are not enough for space heating, the VI-ASHP operates to meet the heating load, which is shown in Fig. 2(c);

Table 1

Technical specifications for the components of the system.

\begin{tabular}{|l|l|l|l|}
\hline Name & Size & Number & Technical index \\
\hline PV panels & $1 \mathrm{~m} \times 2 \mathrm{~m}$ & 4 & Crystalline silicon solar cells \\
\hline Solar thermal panels & $1 \mathrm{~m} \times 2 \mathrm{~m}$ & 8 & Mini-channels \\
\hline VI-ASHP & $1.5 \mathrm{~m} \times 0.5 \mathrm{~m} \times 1 \mathrm{~m}$ & 1 & $\begin{array}{l}\text { Nominal condition heating output: } \\
12000 \mathrm{~W}\end{array}$ \\
\hline $\begin{array}{l}\text { Heat storage and exchange } \\
\text { unit }\end{array}$ & $\begin{array}{l}\text { Diameter: } 1.19 \mathrm{~m}, \text { Height: } \\
1.38 \mathrm{~m}\end{array}$ & 1 & Volume: $1.5 \mathrm{~m}^{3}$ \\
\hline Under floor coil & Diameter: $16 \mathrm{~mm}$ & $300 \mathrm{~m}$ & Material: PE-X \\
\hline
\end{tabular}

\section{Fig. 2}

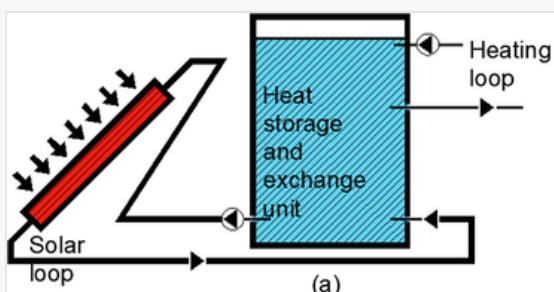

(a)

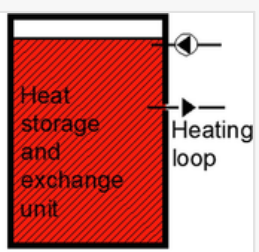

(b)

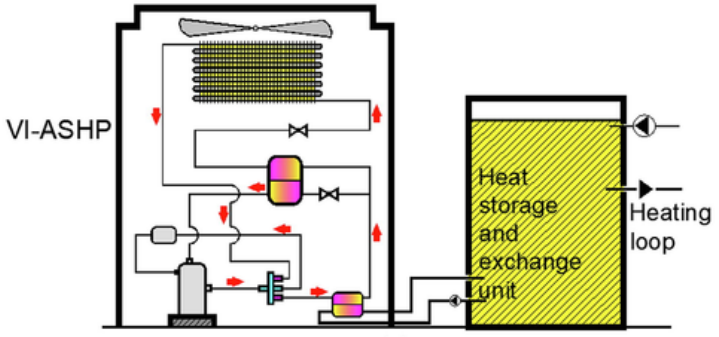

(c)

Heating process of the proposed system.

The processes for domestic hot water supply and cooling are relatively simple. For domestic hot water, when the water tank temperature rises to $50{ }^{\circ} \mathrm{C}$, hot water can be supplied by opening the hot water tap directly. For the cooling process, the VI-ASHP can exchange the circular route between the evaporator and condenser by using a four-way reversing valve and hence supply cooling directly through the under-floor coil, as shown in Fig. 3. 


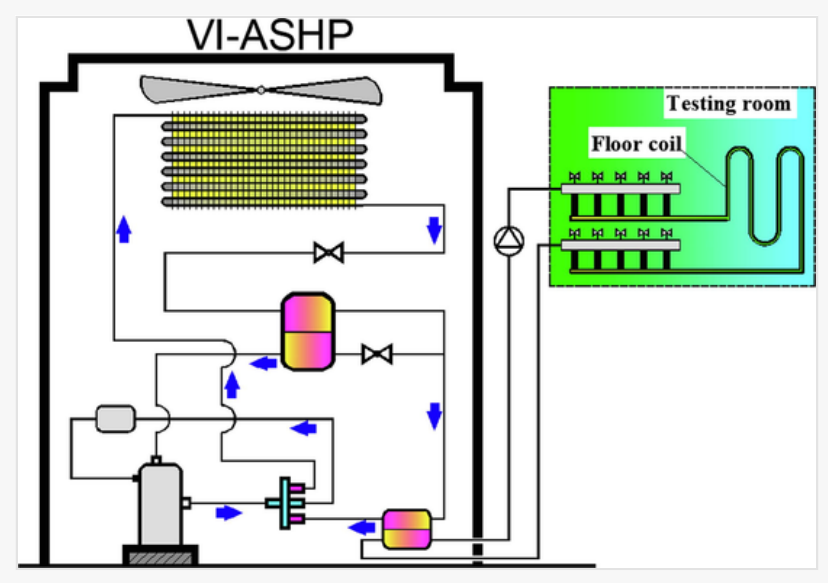

Cooling process of the proposed system.

Consequently, the proposed system can provide space heating, cooling and hot water with low electricity consumption and reduced electricity cost. Several indexes, including the systems energy consumption, systems cost, cost payback period and contaminant generation are employed to evaluate the performance of the system relative to coal-powered systems. The heating, cooling and hot water supply processes of the two systems are shown in Fig. 4. To provide a reference point for comparison, the performance of a conventional coal-based system is also analysed.

\section{Fig. 4}

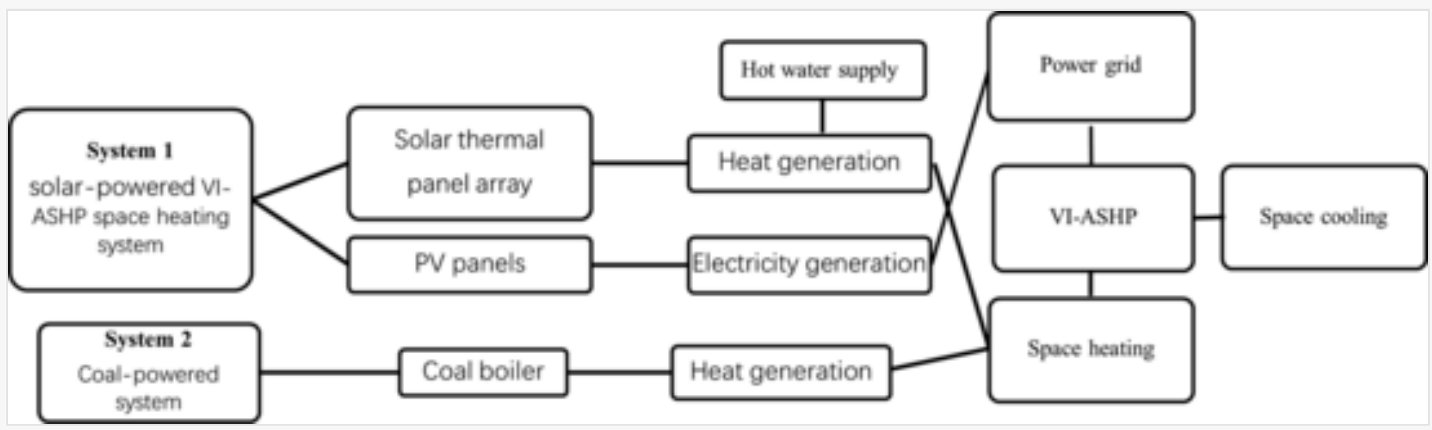

The heat generation processes of the systems.

\section{Mathematical models}

The corresponding initial and boundary conditions, i.e. solar radiation, air temperature, wind speed and water temperature were extracted from the weather database by using Energy-Plus software (537720_CSWD) for Taiyuan[29]. During the operation of the model, it is assumed that the system works $24 \mathrm{~h}$ every day, and the heat pump operates at a condensation temperature of $50{ }^{\circ} \mathrm{C}$ for space heating in winter and an evaporation temperature of $10^{\circ} \mathrm{C}$ for cooling in summer. The installation angles of solar PV and thermal panels are the same as the local altitude in the city. The economic figures, such as capital cost, renewable feed-in tariffs, system life span and air contaminant emission factors are also input into the program for calculation. The algorithm is presented in a flow diagram in Fig. 5, as explained below:

(1) Input the design/operating parameters of the models for the solar thermal panel array, PV panels, house and VI-ASHP into program code. 
(2) Input the external boundary conditions from the weather data file, and divide the weather date into 262,800 parts throughout the year, thus giving a time step of $120 \mathrm{~s}$. The calculation begins with the first weather data $(t=1)$.

(3) Calculate the heating and cooling load, heat collected from the solar panel array, heat deficit, and electricity generated by the PV panels.

(4) Calculate the electricity consumption of the system.

(5) Move to the next step $(t=t+120)$ and repeat the calculation until $t=262800$.

(6) Carry out an energetic performance analysis of two systems.

(7) Carry out an economic and environmental performance analysis of two systems.

(8) Program stops.

\section{Fig. 5}

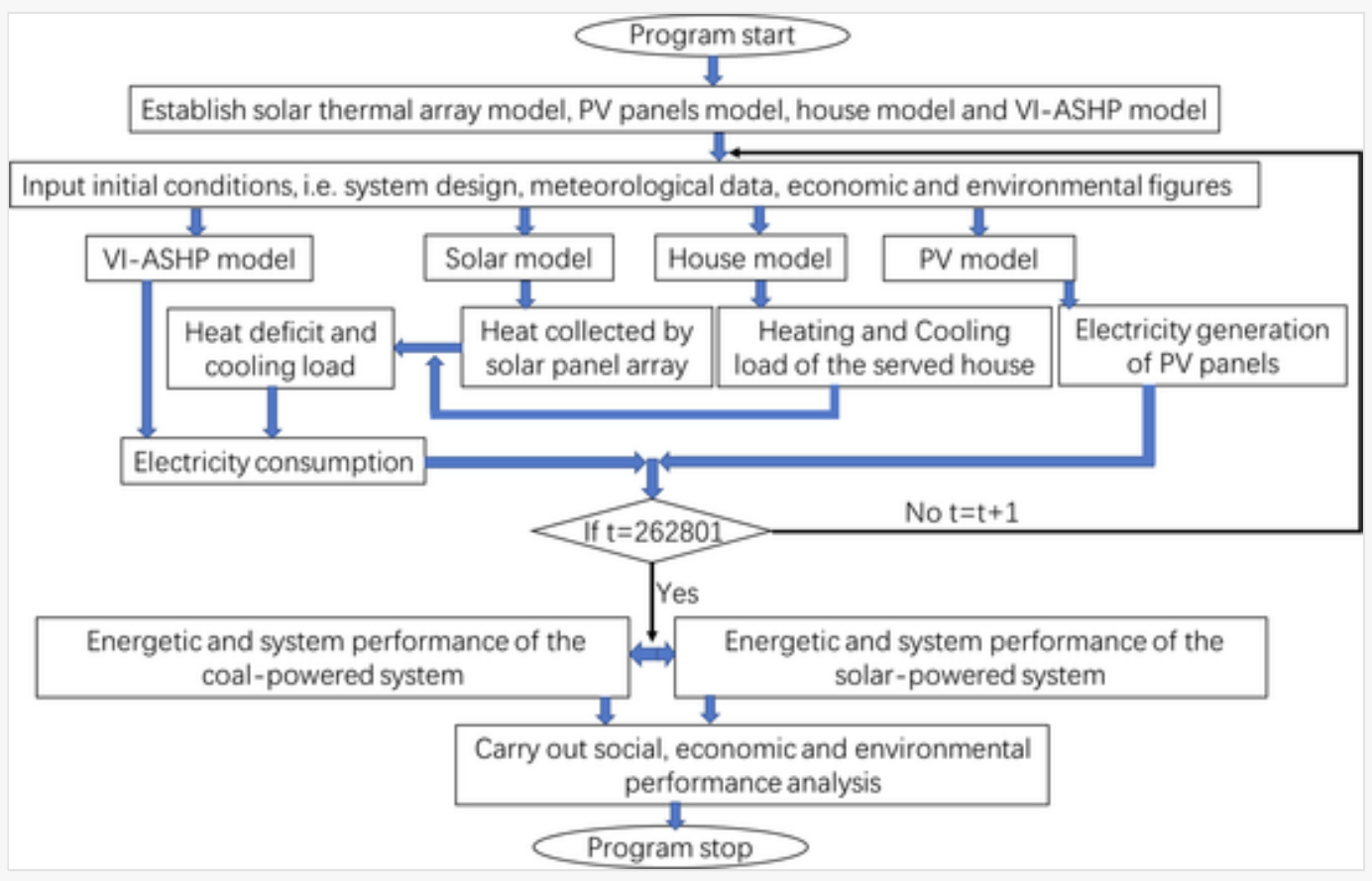

The calculation process of the model.

\subsection{Heating and cooling load of the served house}

The heating load of the served house in winter is mainly dependent on the difference between the room temperature (set at $16{ }^{\circ} \mathrm{C}$ ) and the ambient temperature. It can be calculated based on the local weather data (Taiyuan city, Shanxi province).

The equation for the heating load can be given as:

$$
Q_{\text {h.l }}=Q_{\text {h.l.am }}+Q_{\text {h.l.wind }}
$$

In Eq. (1), the heating load of house envelops $Q_{\text {h.l.am }}$ can be expressed as: 
In order to take solar radiation as an impact factor, the orientation correction coefficients are integrated into the heat load calculation. In Eq.2, $\alpha_{\text {h.l.e }}, \alpha_{\text {h.l.w }}, \alpha_{h . l . s}$ and $\alpha_{h . l . n}$ are the coefficients of the house envelops orientation correction facing east, west, south and north separately, and the values of which are $-5 \%,-5 \%,-15 \%$ and $5 \%$ respectively [30]. $S_{e . e}, S_{e . w}, S_{e . s}$ and $S_{e . n}$ stand for the envelopes area facing corresponding direction, $\mathrm{m}^{2}$. In addition, the heating load of house cold air infiltration $Q_{\text {h.l.wind }}$ can be expressed as:

$$
Q_{\text {h.l.wind }}=0.28 C p_{\text {air }} \rho_{\text {air }} L_{\text {air }}\left(T_{r . h l}-T_{a}\right)
$$

In Eq.3, the cold air infiltration volume per hour $L_{\text {air }}$ can be expressed as:

$$
L_{\text {air }}=L_{0} l_{0}
$$

In Eq.4, the cold air infiltration volume per hour per meter $L_{0}$ can be expressed as:

$$
L_{0}=\alpha_{\text {air }}\left(\frac{\rho_{\text {air }}}{2} v_{0}^{2}\right)^{b}
$$

In Eq.5, $\alpha_{\text {air }}$ is the coefficient of air permeability of outer doors and windows, $\mathrm{m}^{3} /(\mathrm{m} \cdot \mathrm{h} \cdot \mathrm{Pa})$, the value of which can take 0.15 for residential building. $v_{0}$ is the local average wind velocity in the winter, $\mathrm{m} / \mathrm{s}$, the value of which can take 3.4 for Taiyuan city. $b$ is the index of the air permeability of outer doors and windows, the value of which can take 0.67 for residential buildings [30].

The cooling load of the served house in summer is mainly determined by the difference between the room temperature (set at $24{ }^{\circ} \mathrm{C}$ ) and the ambient temperature. It can be calculated by:

$$
Q_{c . l}=Q_{\text {c.l.am }}+Q_{\text {c.l.solar }}+Q_{\text {c.l.people }}
$$

In Eq.6, the house envelops cooling load $Q_{\text {c.l.am }}$ can be expressed as:

$$
Q_{\text {c.l.am }}=\tau_{c . l} h_{t} S_{e}\left(T_{\text {r.c.l }}-T_{a}\right)
$$

In Eq.6, the cooling load generated by solar radiation $Q_{\text {c.l.solar }}$ can be expressed as: 
In Eq.8, $C_{c l C}$ is the solar radiation cooling load factor. The value of $C_{c l C}$ is determined by the orientation and the time and can be obtained from a local building design standard, GB 50736-2012. $D_{\text {J.max }}$ is the maximum index of the local solar radiation passing a glass in summer, which is 570 for Taiyuan city. The comprehensive shielding coefficient of the outer window $C_{z}$ can be expressed as:

$$
C_{z}=C_{w} C_{n} C_{s}
$$

In Eq.9, $C_{w}$ is the outer shielding device correction factor, $C_{n}$ is the inner shielding device correction factor, $C_{s}$ is the window glass correction factor. For the normal residential building with double-layer glass, $C_{w} 0.95$ is $C_{n}$ is 0.9 , and $C_{s}$ is 1 .

In Eq.6, the inner cooling load generated by body heat dissipation $Q_{\text {c.l.people }}$ can be expressed as:

$$
Q_{\text {c.l.people }}=C_{\text {people }} \varnothing Q_{\text {people }}
$$

In Eq.10, $C_{\text {people }}$ is the number of people. $\emptyset$ is the clustering coefficient. $Q_{\text {people }}$ is the maximum body heat dissipation generated by one person, $\mathrm{W}$.

\subsection{Collected solar energy by PV and solar thermal collectors}

The collected energy from the solar system is divided into two parts, i.e. solar heat from the mini-channel panel array and electricity generated by the PV panels.

\subsubsection{Collected solar thermal energy by mini-channel solar thermal panel array}

The solar thermal energy output from the solar thermal panel array during the heating season can be expressed as:

$$
Q_{s t}=A_{s t} I \eta_{o t} \tau_{s t}
$$

In the simulation, 8 thermal panels are connected in a multiple-throughout-flowing loop. The solar thermal efficiency of a single panel can be expressed as [9]:

$$
\eta_{i t}=0.87-3.7 \frac{T_{i n}-T_{a}}{I}
$$


For each individual panel in a multiple-throughout-flowing configuration, the solar thermal efficiency is given by [9]:

$\eta_{1}=\left(\frac{C p_{w f} \dot{m}\left(t_{1}-t_{0}\right)}{\frac{I A}{3}}+\frac{C p_{w f} \dot{m}\left(t_{16}-t_{15}\right)}{\frac{I A}{3}}+\frac{C p_{w f} \dot{m}\left(t_{17}-t_{16}\right)}{\frac{I A}{3}}\right) / 3$

$\eta_{2}=\left(\frac{C p_{w f} \dot{m}\left(t_{2}-t_{1}\right)}{\frac{I A}{3}}+\frac{C p_{w f} \dot{m}\left(t_{15}-t_{14}\right)}{\frac{I A}{3}}+\frac{C p_{w f} \dot{m}\left(t_{18}-t_{17}\right)}{\frac{I A}{3}}\right) / 3$

$\eta_{3}=\left(\frac{C p_{w f} \dot{m}\left(t_{3}-t_{2}\right)}{\frac{I A}{3}}+\frac{C p_{w f} \dot{m}\left(t_{14}-t_{13}\right)}{\frac{I A}{3}}+\frac{C p_{w f} \dot{m}\left(t_{19}-t_{18}\right)}{\frac{I A}{3}}\right) / 3$

$\eta_{4}=\left(\frac{C p_{w f} \dot{m}\left(t_{4}-t_{3}\right)}{\frac{I A}{3}}+\frac{C p_{w f} \dot{m}\left(t_{13}-t_{12}\right)}{\frac{I A}{3}}+\frac{C p_{w f} \dot{m}\left(t_{20}-t_{19}\right)}{\frac{I A}{3}}\right) / 3$

$\eta_{5}=\left(\frac{C p_{w f} \dot{m}\left(t_{5}-t_{4}\right)}{\frac{I A}{3}}+\frac{C p_{w f} \dot{m}\left(t_{12}-t_{11}\right)}{\frac{I A}{3}}+\frac{C p_{w f} \dot{m}\left(t_{21}-t_{20}\right)}{\frac{I A}{3}}\right) / 3$

$\eta_{6}=\left(\frac{C p_{w j} \dot{m}\left(t_{6}-t_{5}\right)}{\frac{I A}{3}}+\frac{C p_{w f} \dot{m}\left(t_{11}-t_{10}\right)}{\frac{I A}{3}}+\frac{C p_{w f} \dot{m}\left(t_{22}-t_{21}\right)}{\frac{I A}{3}}\right) / 3$

$\eta_{7}=\left(\frac{C p_{w f} \dot{m}\left(t_{7}-t_{6}\right)}{\frac{I A}{3}}+\frac{C p_{w f} \dot{m}\left(t_{10}-t_{9}\right)}{\frac{I A}{3}}+\frac{C p_{w f} \dot{m}\left(t_{23}-t_{22}\right)}{\frac{I A}{3}}\right) / 3$

$\eta_{8}=\left(\frac{C p_{w f} \dot{m}\left(t_{8}-t_{7}\right)}{\frac{I A}{3}}+\frac{C p_{w f} \dot{m}\left(t_{9}-t_{8}\right)}{\frac{I A}{3}}+\frac{C p_{w f} \dot{m}\left(t_{24}-t_{23}\right)}{\frac{I A}{3}}\right) / 3$

The overall solar thermal efficiency of the mini-channel solar thermal panel array can be expressed as:

$\eta_{o t}=C p_{w f} \dot{m}\left(t_{24}-t_{0}\right) /(8 I A)$ 


\subsubsection{Electricity generation by $P V$ panels}

The electricity generated by a PV panel can be expressed as[31]:

$$
Q_{s e}=N A_{e} I \eta_{e} \tau_{w y}
$$

The photoelectric efficiency of the PV panel can be expressed as:

$$
\eta_{e}=\eta_{r c}\left[1-\beta_{P V}\left(T_{c}-T_{r c}\right)\right]
$$

The temperature of the PV cell can be expressed as:

$$
T_{c}=T_{a}+\frac{(N O T C-20)}{0.8} I
$$

\subsection{Energy consumption of the systems}

\subsubsection{Electricity consumption of the VI-ASHP}

The electricity consumed by the VI-ASHP for winter heating can be expressed as[32]:

$$
Q_{e c . w h}=\frac{Q_{h d}}{C O P}
$$

$Q_{h d}$ is the heat deficit of the system, which can be expressed as:

$$
Q_{h d}=Q_{h . l}-Q_{s t}
$$

The electricity consumed by the VI-ASHP for summer cooling can be expressed as[32]:

$$
Q_{e c . \mathrm{sc}}=\frac{Q_{c l}}{E E R}
$$

Cooperating with the mini-channel solar thermal panel array, a VI-ASHP is applied to provide heating in winter and cooling in summer. The coefficient of performance for winter heating $(C O P)$ and energy efficiency ratio for 
summer cooling $(E E R)$ are modelled based on the performance of a commercialised VI-ASHP by Emerson Electric Co. [33]. COP can be expressed as:

$$
C O P=\frac{Q_{h p}}{W_{e c}}
$$

EER can be expressed as[34]:

$$
E E R=\frac{Q_{c p}}{W_{e c}}
$$

In winter the VI-ASHP operates at a condensation temperature of $50{ }^{\circ} \mathrm{C}$ for space heating. Within the evaporator, the temperature difference between ambient air and exhaust air is $5{ }^{\circ} \mathrm{C}$. Similarly, the temperature difference between the exhaust air and the evaporation temperature is also $5{ }^{\circ} \mathrm{C}$, leading to a temperature difference between ambient temperature and evaporation temperature of refrigerant of $10{ }^{\circ} \mathrm{C}$. The performance of the VI-ASHP for heating is shown in Fig. 6. According to the performance curve, the relationship between ambient temperature and $\mathrm{COP}$ can be expressed as:

$$
C O P=0.000764575 * T_{a m}^{2}+0.062569118 * T_{a m}+2.922993
$$

\section{Fig. 6}

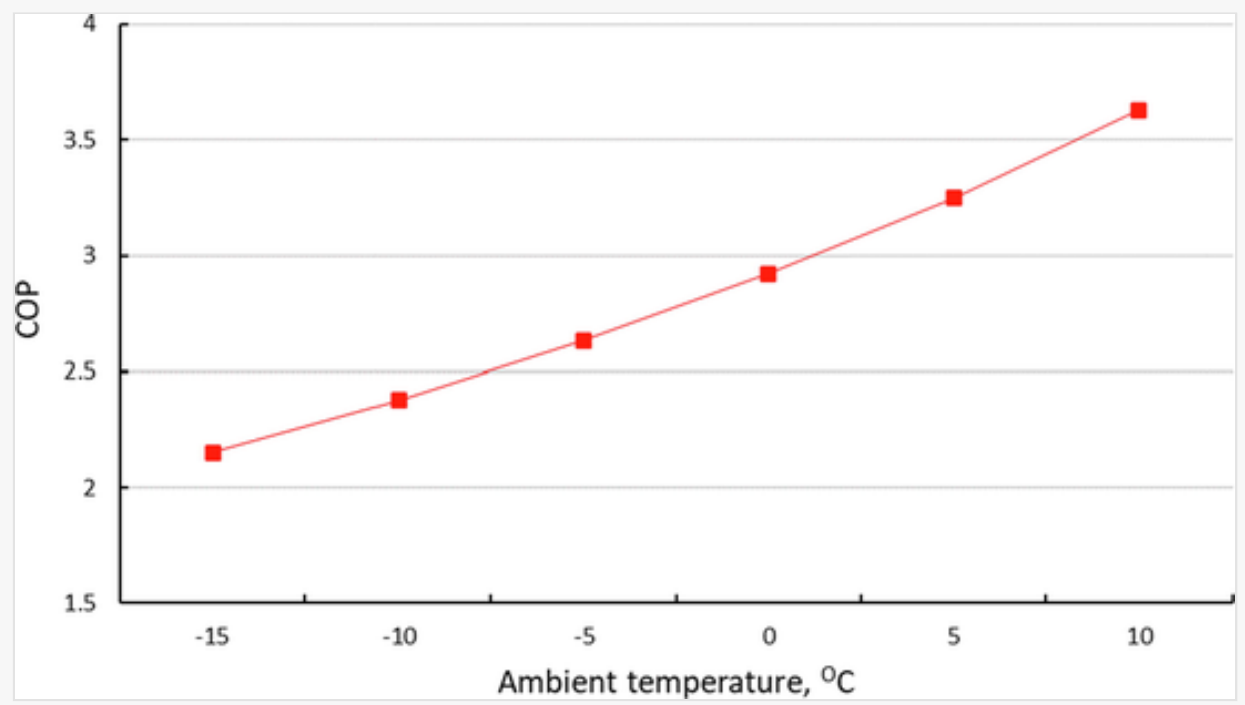

The COP of the VI-ASHP in heating.

In summer, the VI-ASHP operates in cooling mode, in which the evaporation temperature is set to $10{ }^{\circ} \mathrm{C}$ for cooling. Similarly, with the heating mode, the temperature difference between the ambient air and condensation temperature of the refrigerant is $10{ }^{\circ} \mathrm{C}$. The performance of the VI-ASHP for cooling is shown in Fig. 7. 
According to the performance curve, the relationship between ambient temperature and EER can be expressed as:

$E E R=0.001591963 * T_{a m}^{2}-0.238768127 * T_{a m}+10.56483$

\section{Fig. 7}

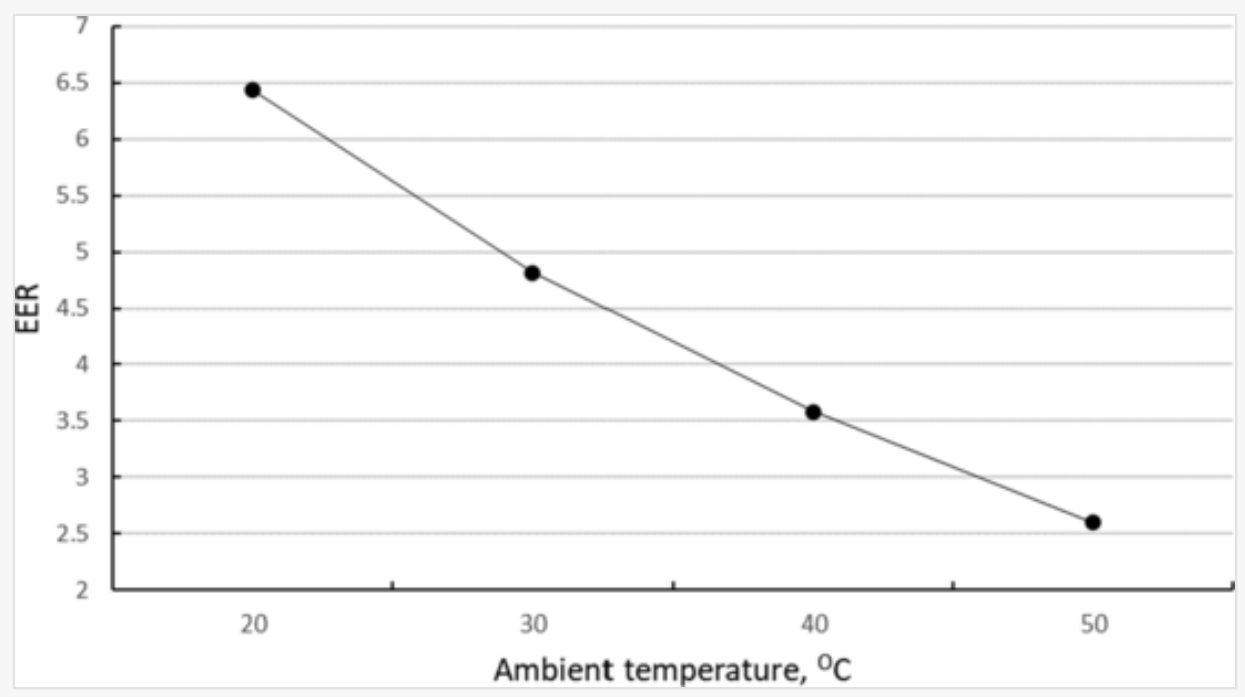

The EER of the VI-ASHP in cooling.

\subsubsection{Electricity consumption of the water pump}

The electricity consumed by the water pump of the system can be expressed as:

$$
Q_{e c . w p}=P_{w p} \hat{A} \cdot \tau_{w p}
$$

\subsubsection{Coal consumption of the coal-based system}

The coal consumed by a coal-powered system can be given as:

$$
Q_{d}=q_{c} m_{c . c} \eta_{c}
$$

Where $q_{c}$ is the calorific value generated by anthracite coal, which is $8 \mathrm{kWh} / \mathrm{kg}$ [35]; $m_{c . c}$ is the consumed anthracite coal by a coal-based heating system, $\mathrm{kg} ; \eta_{c}$ is the heating efficiency, which is $75 \%$ in the simulation [36].

\subsection{Economic analysis of the systems}


The initial capital cost of the novel solar-assisted VI-ASHP space heating system includes the individual cost of all the system components. A mark up of $20 \%$ is adopted to allow for commercial profits. The basic equipment cost is mainly divided into five parts: the solar thermal panel array; PV panels; heat storage and exchange unit; VI-ASHP and all other miscellaneous costs, which include additional equipment such as pipes and pipe fittings, water pump, grid inverter and installation cost. Consequently, the initial capital cost can be expressed as:

$$
C_{c, s p}=\left(\mathrm{C}_{P T}+\mathrm{C}_{P V}+\mathrm{C}_{H S E U}+\mathrm{C}_{H P}+\mathrm{C}_{A D D}\right) \hat{A} \cdot(1+20 \%)
$$

The other cost $\mathrm{C}_{A D D}$ is assumed to be $10 \%$ of the equipment cost, and is expressed as[37]:

$$
\mathrm{C}_{A D D}=\left(\mathrm{C}_{P T}+\mathrm{C}_{P V}+\mathrm{C}_{H S E U}+\mathrm{C}_{H P}\right) \hat{A} \cdot 10 \%
$$

The equivalent payback period (PP) of this novel solar-assisted VI-ASHP system to replace a conventional coalbased system can be expressed as[37]:

$$
P P_{s p}=\frac{\text { CapitalCost }- \text { Incentives }}{\text { Annual (Operational\&maintenance) CostSaving }}
$$

$$
P P_{s p-c}=\frac{C_{c, s p}-C_{c, c}-C_{R E}}{\left(C_{o, c}+C_{m, c}\right)-\left(C_{o, s p}+C_{m, s p}\right)}
$$

Where $C_{o, s p}$ and $C_{m, s p}$ are operational and maintenance costs of the novel system.

To support the installation of a renewable energy system it may be possible to receive grants through the government's renewable policy. For example, the Renewable Heat Incentive (RHI) scheme is intended to encourage the uptake of renewable heating technologies within households, communities and businesses through the provision of financial incentives. Whilst there is currently no financial incentive for solar thermal energy, the current feed-in tariff price for photovoltaic electricity is ' $¥ 0.75 / \mathrm{kWh}$ ’ for Shanxi[38]. As a result, the ultimate operational cost of such a system equals the basic operational cost including the operational cost by the VIASHP and water pumps minus the total earning of the generated electricity, which can be expressed by

$$
C_{o, s p}=C_{o, h p}+C_{o, w p}-C_{t e}
$$

The maintenance cost of the three systems is normally estimated at $2 \%$ of the initial system cost[39]. As a solarbased system is usually considered to have a lifespan of 25 years[40], the life-cycle net cost saving, $C S_{s p}$, of this system in energy bills can be determined by 


$$
C S_{s p-c}=\left(25-P P_{s p-c}\right)\left[\left(C_{o, c}+C_{m, c}\right)-\left(C_{o, s p}+C_{m, s p}\right)\right]
$$

\subsection{Contaminants analysis}

Four kinds of air contaminations, $\mathrm{CO}_{2}$, harmful dust, $\mathrm{SO}_{2}$, and $\mathrm{NO}_{\mathrm{x}}$, are taken into consideration in this paper and the quantity can be expressed as:

$$
m_{p . c}=m_{p u . c} m_{c . c}
$$

Where $m_{p . c}$ is the mass of air contaminations generated by the coal-based heating system, $\mathrm{kg}$; and $m_{\text {pu.c }}$ is the mass of air contaminations generated by per unit anthracite coal separately, $\mathrm{kg} / \mathrm{kg}$.

\section{Case study model}

In this section, a rural house located in Taiyuan City, Shanxi Province in northern China $\left(37.52^{\circ} \mathrm{N}, 111.15^{\circ} \mathrm{E}\right)$ is selected as a case study. The system provides space heating, cooling, and domestic hot water flexibly. The served house has an area of $100 \mathrm{~m}^{2}$, a length of $14 \mathrm{~m}$, a width of $7 \mathrm{~m}$ and a height of $4 \mathrm{~m}$. The front façade of the house faces south. The schematic of the served house is shown in Fig. 8, and the heat transfer coefficients of the building envelopes are listed in Table 2 . The thermal properties of the building components are the same as the actual parameters for a common rural house, thus providing an accurate reflection of the heat load for a rural house.

\section{Fig. 8}

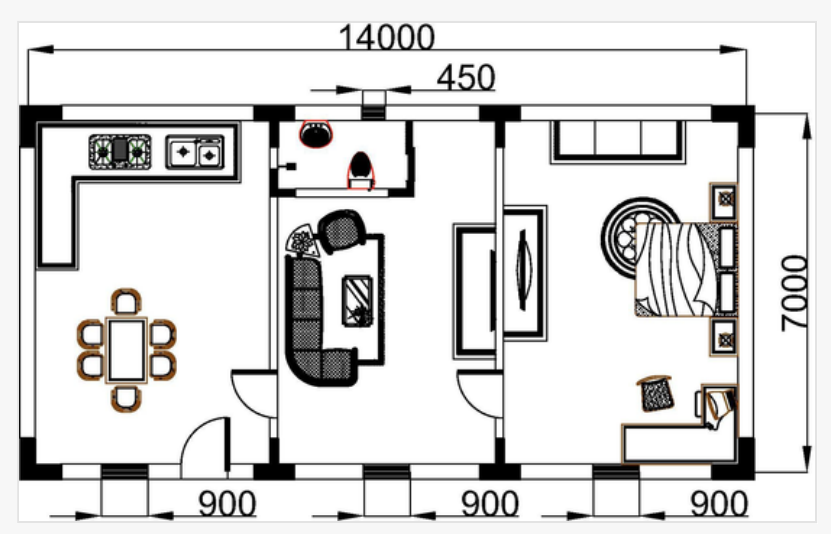

The floor plan and corresponding dimensions of the served house. 
The heat transfer coefficients of the building envelope.

\begin{tabular}{|l|l|l|}
\hline Part & Structure & K $\left[\mathbf{W} /\left(\mathbf{m}^{2} \cdot{ }^{\circ} \mathbf{C}\right)\right]$ \\
\hline Wall & $370 \mathrm{~mm}$ brick wall Plastering $+50 \mathrm{~mm}$ extruded polystyrene board & 0.47 \\
\hline External doors & Pinewood door & 2.9 \\
\hline Window & 3 mm common glass aluminium alloy window frame (two layers) & 1.54 \\
\hline Roof & Cement mortar + Insulation layer + Waterproof layer + Tile. & 0.37 \\
\hline
\end{tabular}

The hourly dry-bulb ambient temperature and the solar radiation variation for a whole year in Taiyuan city are shown in Fig. 9 and Fig. 10 separately. The ambient dry-bulb temperature varies from $-15{ }^{\circ} \mathrm{C}$ to $35{ }^{\circ} \mathrm{C}$. The highest ambient dry-bulb temperature reaches $35{ }^{\circ} \mathrm{C}$ on the initial days of July, and the lowest ambient temperature reaches $-15^{\circ} \mathrm{C}$ during January.

\section{Fig. 9}

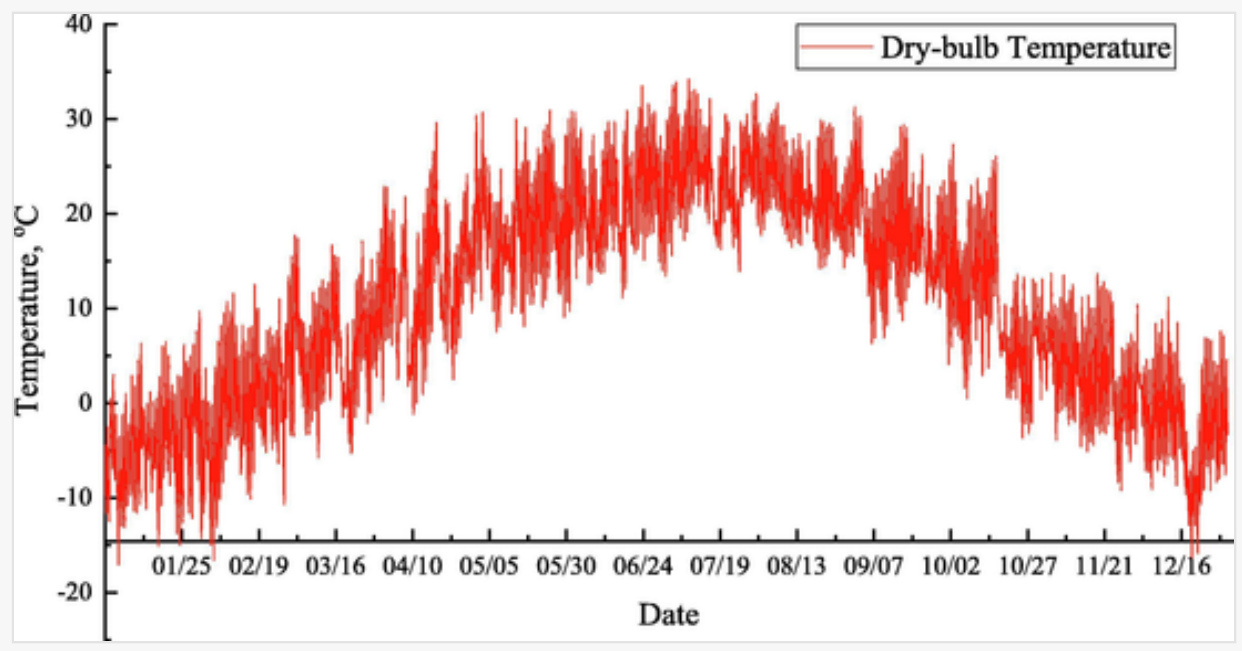

The hourly ambient dry-bulb temperature variation along a year. 


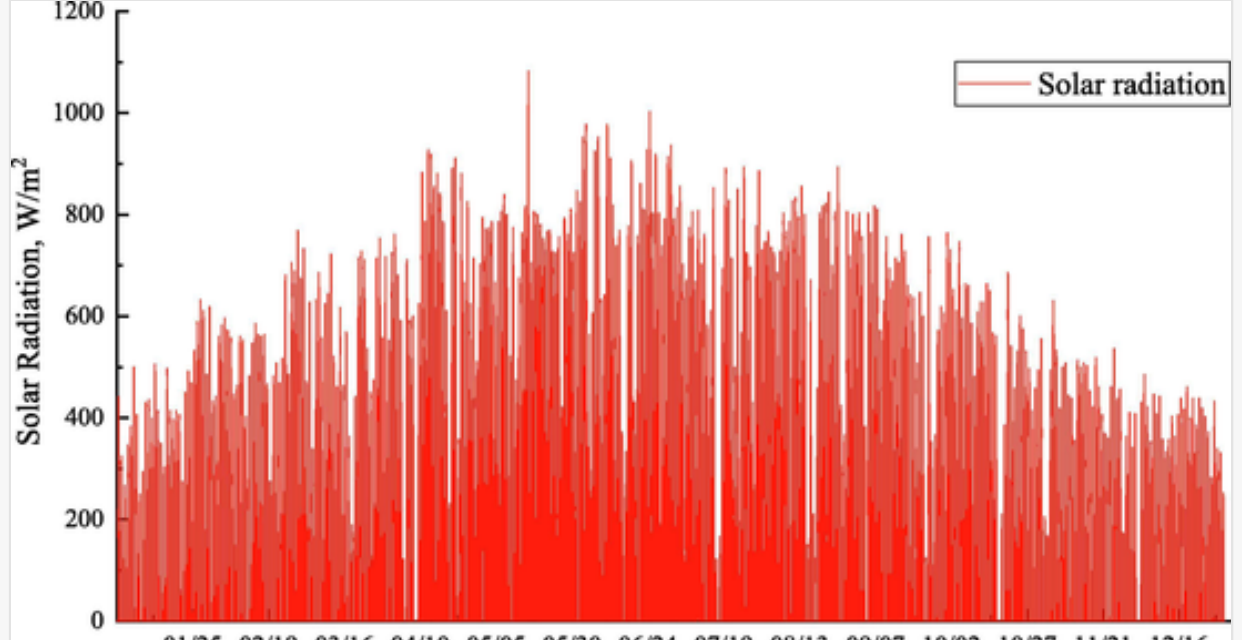

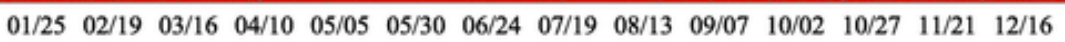

Date

The hourly solar radiation variation along a year.

The hourly solar radiation variation is similar to the trend of ambient temperature which is shown in Fig. 10. During the summer months, from May to August, the highest solar radiation can reach $900 \mathrm{~W} / \mathrm{m}^{2}$ to $1000 \mathrm{~W} / \mathrm{m}^{2}$. And during the winter months, from November to December, the lowest solar radiation falls to $400 \mathrm{~W} / \mathrm{m}^{2}$ to $500 \mathrm{~W} / \mathrm{m}^{2}$.

\section{Results and discussion}

\subsection{Thermal performance}

According to the local weather conditions, the daily collected solar heat, daily heating load during winter and daily cooling load during summer can be simulated as shown in Fig. 11. During the heating season in winter, the heat load often surpasses the collected heat due to the low solar radiation and ambient temperature. More panels can be employed to increase the solar heat gain; however, the roof area and cost limit this option. During some periods from the 1st of April to the 15th of May and from the 1st of September to the 10th of October, both cooling and heating are required in a single day. Nonetheless, owing to the flexibility of the proposed system, it can perfectly fit the polytropic and complicated thermal environment, and maintain the room temperature at a relatively stable range, i.e. $16{ }^{\circ} \mathrm{C}$ to $24^{\circ} \mathrm{C}$. 


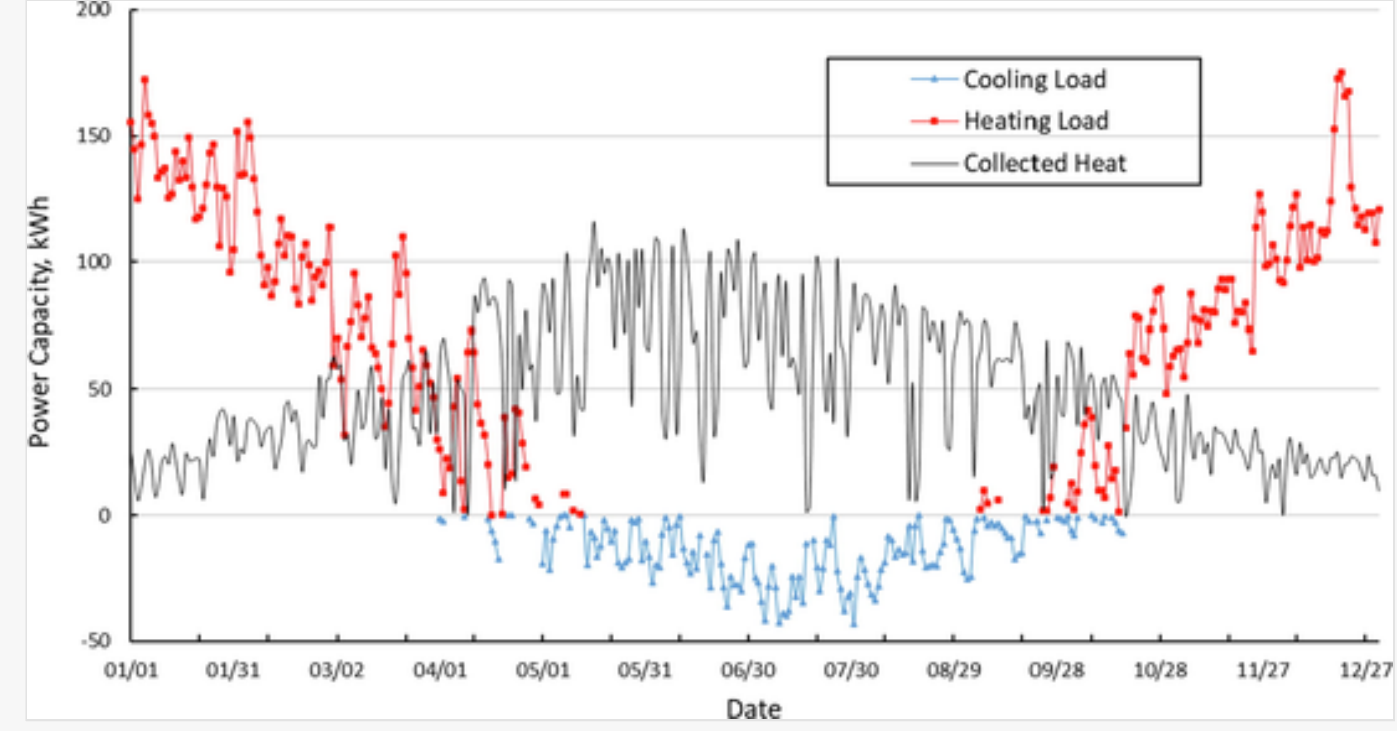

Daily variations of the solar energy collection, heating and cooling load along a year.

Table 3 shows the monthly collected heat, heating load and cooling load summarized from Fig. 11. The annual space heating load and the collected heat of the system are 17538kWh and 17770kWh separately. From January to April, and October to December, the heat load is higher than the collected heat, the highest monthly heat deficit peaks at $3465.3 \mathrm{kWh}$ in January and the total heat deficit is $12010.6 \mathrm{kWh}$ for the winter months. From May to September, the collected heat is higher than the heat load and most solar heat can be used to generate domestic hot water, which is a good advantage of the system. Due to the spare heat from May to September, the system can provide a total of 274.5 tons of domestic hot water, which can save $12262.6 \mathrm{kWh}$ of energy. The annual cooling load of the house is $2311 \mathrm{kWh}$.

(i) The table layout displayed in this section is not how it will appear in the final version. The representation below is solely purposed for providing corrections to the table. To preview the actual presentation of the table, please view the Proof.

Monthly heating and cooling load and heat deficit.

\begin{tabular}{|c|c|c|c|c|c|c|}
\hline Month & Jan & Feb & Mar & Apr & May & Jun \\
\hline Cooling Load (kWh) & 0 & 0 & 0 & 43.89 & 263.6 & 495.57 \\
\hline Heating Load (kWh) & 4161.98 & 3055.84 & 2028.57 & 736.25 & 19.03 & 0 \\
\hline Heat Deficit (kWh) & 3465.31 & 2098.64 & 785.32 & 198.63 & 0 & 0 \\
\hline Month & Jul & Aug & Sep & Oct & Nov & Dec \\
\hline Cooling Load (kWh) & 798.45 & 480.54 & 190.37 & 38.16 & 0 & 0 \\
\hline
\end{tabular}




\begin{tabular}{|l|l|l|l|l|l|l|}
\hline Heating Load $(\mathrm{kWh})$ & 0 & 0 & 53.56 & 1224.82 & 2525.56 & 3732.83 \\
\hline Heat Deficit $(\mathrm{kWh})$ & 0 & 0 & 0 & 552.12 & 1721.72 & 3142.04 \\
\hline
\end{tabular}

Given the ambient temperature, the daily average COP in winter and EER in summer of VI-ASHP are shown in Fig. 12. The results show that the EER of the VI-ASHP is higher than the COP, indicating that the electricity consumption for winter heating will be higher than that for summer cooling at the same load. Considering the heating load is significantly higher than the cooling load, the device selection of VI-ASHP in temperate continental monsoon climate areas, such as Taiyuan city, should put heating performance a priority. Moreover, the shaded area in Fig.21 shows that the VI-ASHP needs to supply heating and cooling during a single day to keep a high level of indoor thermal comfort.

\section{Fig. 12}

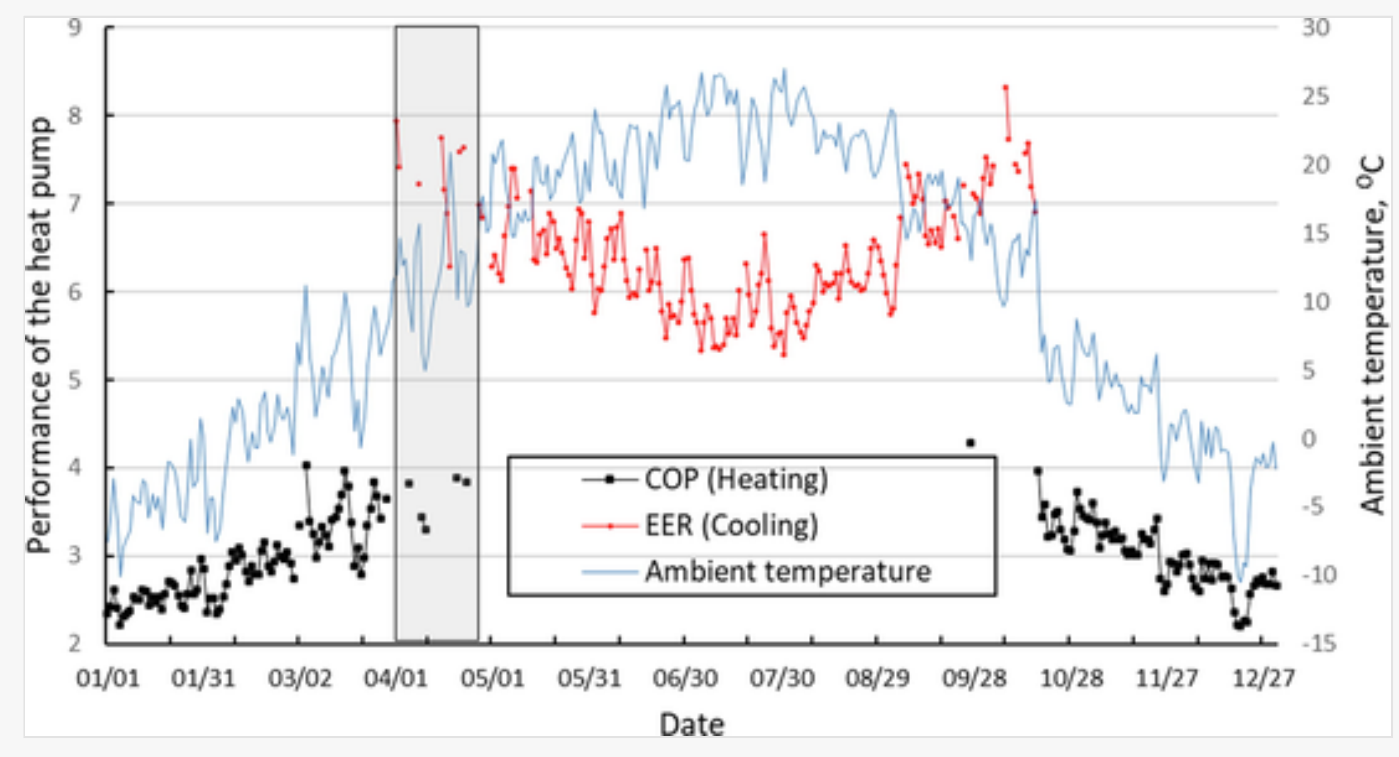

The daily COP and EER variations of the VI-ASHP over a whole year.

\subsection{Electrical performance}

\subsubsection{Electricity consumption of the system}

The heat deficit can be calculated by the difference between the heating load and heat collection. In addition, as shown in Fig. 13, the daily electricity consumption of the system can be obtained based on heat deficit in winter, cooling load in summer, COP and EER of the VI-ASHP. Obviously, the electricity consumption of heating during the winter is much higher than that of cooling during the summer. The daily electricity consumption for heating peaks at $74 \mathrm{kWh}$ in December, while the highest electricity consumption for cooling is just $8 \mathrm{kWh}$ in July. 
i The table layout displayed in this section is not how it will appear in the final version. The representation below is solely purposed for providing corrections to the table. To preview the actual presentation of the table, please view the Proof.

Monthly operation time of the water pump.

\begin{tabular}{|l|l|l|l|l|l|l|}
\hline Month & Jan & Feb & Mar & Apr & May \\
\hline Monthly Water Pump Operation Time (h) & 219 & 229 & 269 & 285 & 352 & 317 \\
\hline Month & Jul & Aug & Sep & Oct & Nov \\
\hline Monthly Water Pump Operation Time (h) & 311 & 302 & 267 & 246 & 219 & 210 \\
\hline
\end{tabular}

\subsubsection{Electricity generation of the system}

There are four photovoltaic panels, and each has an aperture area of $2 \mathrm{~m}^{2}$. The electricity generation per square meter every month is shown in Table 6 , which is $216.2 \mathrm{kWh} / \mathrm{m}^{2}$ annually. Hence, the total photovoltaic electricity production is $1729.6 \mathrm{kWh}$. The feed-in tariff in Shanxi is $0.75 \mathrm{RMB} / \mathrm{kWh}$, which means that the served house can earn a total of 1297.2RMB per year by transferring the generated electricity into the power grid.

Table 6

(i) The table layout displayed in this section is not how it will appear in the final version. The representation below is solely purposed for providing corrections to the table. To preview the actual presentation of the table, please view the Proof.

Electricity generated monthly per square meter of PV panel.

\begin{tabular}{|c|c|c|c|c|c|c|c|c|c|c|c|c|}
\hline month & 1 & 2 & 3 & 4 & 5 & 6 & 7 & 8 & 9 & 10 & 11 & 12 \\
\hline $\begin{array}{l}\text { Solar } \\
\text { irradiation } \\
\left(\mathrm{W} / \mathrm{m}^{2}\right)\end{array}$ & 254 & 333 & 344 & 414 & 488 & 446 & 401 & 396 & 336 & 322 & 270 & 229 \\
\hline $\begin{array}{l}\text { Ambient } \\
\text { temperature } \\
\left({ }^{\circ} \mathrm{C}\right)\end{array}$ & -2.3 & 2.0 & 8.3 & 14.7 & 21.3 & 24 & 26 & 24.2 & 20.1 & 13.2 & 5.8 & 0 \\
\hline $\begin{array}{l}\text { Total working } \\
\text { time (hours) }\end{array}$ & 283 & 256 & 310 & 340 & 372 & 360 & 372 & 372 & 360 & 316 & 270 & 279 \\
\hline $\begin{array}{l}\text { Average } \\
\text { electrical } \\
\text { efficiency }\end{array}$ & $19.4 \%$ & $18.9 \%$ & $18.3 \%$ & $17.6 \%$ & $16.8 \%$ & $16.7 \%$ & $16.7 \%$ & $16.7 \%$ & $17.4 \%$ & $18 \%$ & $18.7 \%$ & $19.3 \%$ \\
\hline $\begin{array}{l}\text { Electricity } \\
\text { generated }\end{array}$ & 12.3 & 14.1 & 17.1 & 21.7 & 26.8 & 23.5 & 21.8 & 21.7 & 18.4 & 16.0 & 12.0 & 10.8 \\
\hline
\end{tabular}


According to the monthly electricity price as displayed in Table 7, the annually earned money from PV panels in the system can buy $1633 \mathrm{kWh}$ of electricity from the grid. The monthly electricity consumption and the corresponding cost of the whole system are shown in Table 8 . The electricity cost in January and December is remarkably higher than that in other months, since the low ambient temperature is accompanied by a high heat load for the building. The total annual electricity cost for the system is 3886RMB. Taking into account the earned 1297.2RMB, the annual operational cost of the system is 2589RMB for space heating, cooling and hot water supply. Overall, the photovoltaic profit provides $27 \%$ of the total operation cost, thereby making the system more economic and considerably decreasing fossil fuel consumption.

Table 7

(i) The table layout displayed in this section is not how it will appear in the final version. The representation below is solely purposed for providing corrections to the table. To preview the actual presentation of the table, please view the Proof.

The electricity utility price.

Utility price $(\mathrm{RMB} / \mathrm{kWh})[41]$

\begin{tabular}{|l|l|l}
\hline$X \leq 170 \mathrm{kWh}$ & $171<\mathrm{X} \leq 260 \mathrm{kWh}$ & $\mathrm{X}>260 \mathrm{kWh}$ \\
\hline 0.477 & 0.527 & 0.777
\end{tabular}

Table 8

(i) The table layout displayed in this section is not how it will appear in the final version. The representation below is solely purposed for providing corrections to the table. To preview the actual presentation of the table, please view the Proof.

Monthly system electricity consumption and cost.

\begin{tabular}{|c|c|c|c|c|c|c|}
\hline Month & Jan & Feb & Mar & Apr & May & Jun \\
\hline Electricity Consumption (kWh) & 1473.51 & 860.41 & 358.74 & 174.17 & 178.30 & 202.64 \\
\hline Electricity Cost (RMB) & 1071.41 & 595.04 & 205.24 & 76.89 & 78.65 & 98.29 \\
\hline Month & Jul & Aug & Sep & Oct & Nov & Dec \\
\hline Electricity Consumption (kWh) & 254.33 & 194.83 & 134.23 & 271.95 & 658.79 & 1278.33 \\
\hline Electricity Cost (RMB) & 125.53 & 80.00 & 59.29 & 137.81 & 438.38 & 919.76 \\
\hline
\end{tabular}


The energy proportions of the system in terms of all energy sources are shown in Table 9, based on the total annual solar thermal energy output and electrical consumption of the system. It is shown that to support the space heating of the simulated house, the energy volumes provided by solar thermal energy, photovoltaic energy and electricity from the power grid are $74.6 \%, 6.9 \%$, and $18.5 \%$ respectively. Hence, the energy supply proportion is about $81.5 \%$ from solar energy, and thus the primary energy source of the system mainly is solar energy.

Annual energy usage breakdowns of the system.

\begin{tabular}{|l|l|l|}
\hline Energy Breakdown & Value (kWh) & Radio (\%) \\
\hline Solar Thermal Energy & 17,770 & 74.6 \\
\hline Photovoltaic Electricity & 1633 & 6.9 \\
\hline Electricity & 4407 & 18.5 \\
\hline
\end{tabular}

\subsection{Economic performance}

\subsubsection{The capital cost of the system}

Because the case study is set under the weather conditions in northern China, the economic analysis in this paper is based on the Chinese market. The initial capital cost of the proposed system is 30290RMB, and a cost breakdown is shown in Table 10. Furthermore, the cost details of the components are presented in Fig. 14. The VI-ASHP is the most expensive component of the system, accounting for nearly $34 \%$ of the total cost. Compared with the solar assisted VI-ASHP system, the coal-based a heating system has a lower initial capital cost of 10400RMB.

Table 10

The table layout displayed in this section is not how it will appear in the final version. The representation below is solely purposed for providing corrections to the table. To preview the actual presentation of the table, please view the Proof.

Initial capital cost of the systems.

\section{Solar assisted VI-ASHP system}

\begin{tabular}{|l|l|l|l|l|}
\hline No. & Component & Quantity/Size & Unit Price (RMB) & Cost (RMB) \\
\hline 1 & PV panels & 4 & 1000 & 4000 \\
\hline 2 & Solar thermal panels & 8 & 787.5 & 6300 \\
\hline
\end{tabular}




\begin{tabular}{|c|c|c|c|c|}
\hline 3 & Heat storage and exchange unit & 1 & 5000 & 5000 \\
\hline 4 & VI-ASHP & 1 & 8000 & 8000 \\
\hline \multicolumn{4}{|c|}{ Additional cost } & $10 \%$ \\
\hline \multicolumn{4}{|c|}{ Additional profit } & $20 \%$ \\
\hline \multicolumn{4}{|c|}{ Initial capital cost (RMB) } & 30,290 \\
\hline \multicolumn{5}{|c|}{ Coal-driven system } \\
\hline No. & Component & Quantity/Size & Unit Price (RMB) & Cost (RMB) \\
\hline 1 & Coal boiler & 1 & 8000 & 8000 \\
\hline \multicolumn{4}{|c|}{ Additional cost } & $10 \%$ \\
\hline \multicolumn{4}{|c|}{ Additional profit } & $20 \%$ \\
\hline \multicolumn{4}{|c|}{ Initial capital cost (RMB) } & 10,400 \\
\hline
\end{tabular}

\section{Fig. 14}

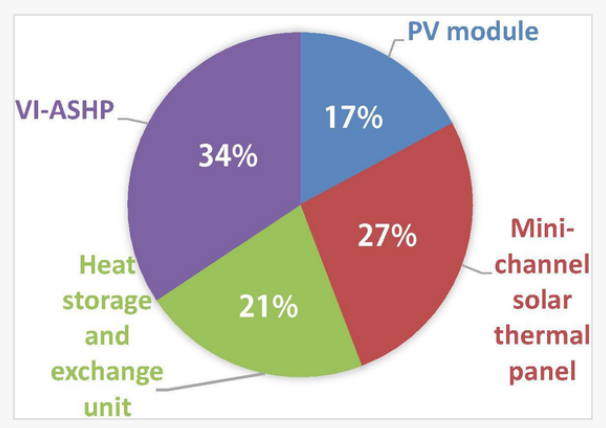

Cost details of the different system components.

\subsubsection{Operational cost, life-cycle and cost payback period compared to the conventional}

\section{heating system}

As discussed above the heat deficit during the space heating season is $12010.6 \mathrm{kWh}$ and the collected solar thermal energy is $17770 \mathrm{kWh}$. This means that the system needs a total heat of $29780.6 \mathrm{kWh}$ annually to provide space heating and domestic hot water.

The annual maintenance cost of a solar heating system is normally estimated at $2 \%$ of the initial system cost, and the annual operating cost of these systems can be estimated as shown in Table 11. Compared with the coaldriven system, this novel system has a cost payback period of 6.52 years and a life-cycle net cost saving of nearly 56328.4RMB in Shanxi. The results show the superior economic performance of the novel solar-powered system.

(i) The table layout displayed in this section is not how it will appear in the final version. The representation below is solely purposed for providing corrections to the table. To preview the actual presentation of the table, please view 
the Proof.

Annual operating costs, cost payback period and Life-cycle cost saving.

\begin{tabular}{|c|c|}
\hline \multicolumn{2}{|l|}{ Solar assisted VI-ASHP system operational performance } \\
\hline The heat produced by solar thermal panel array (kWh/yr.) & 17,770 \\
\hline The energy required from VI-ASHP (kWh/yr.) & 11,687 \\
\hline Total electricity output from the PV module (kWh/yr.) & 1729.6 \\
\hline Electricity consumed by VI-ASHP (kWh/yr.) & 4750 \\
\hline Electricity consumed by the water pump (kWh/yr.) & 1290.4 \\
\hline Operational cost (RMB/yr.) & 2589 \\
\hline Maintenance fee (RMB/yr.) & 717.6 \\
\hline \multicolumn{2}{|l|}{ Coal-based system (efficiency 75\%) } \\
\hline Coal price (Anthracite Coal) (¥/kWh)[42] & 0.152 \\
\hline Capital cost (RMB) & 10,400 \\
\hline Required coal energy (kWh/yr.) & 39707.4 \\
\hline Operational cost (RMB/yr.) & 6035.5 \\
\hline Maintenance fee (RMB /yr.) & 208 \\
\hline Payback period of the solar-powered space heating system (yr.) & 6.52 \\
\hline Life-cycle cost-saving (RMB) & 56328.4 \\
\hline Per $\mathrm{m}^{2}$ life-cycle cost-saving $\left(\mathrm{RMB} / \mathrm{m}^{2}\right)$ & 563.3 \\
\hline
\end{tabular}

\subsection{Environmental performance}

\subsubsection{Annual fossil fuel saving and carbon emission reduction}

Coal is the most common energy source used for conventional heating systems in northern China, with a typical efficiency of $75 \%$ for a domestic heating system. The heat generated by burning $1 \mathrm{~kg}$ of anthracite coal is $8 \mathrm{kWh}$, which means the annual fossil fuel requirement for a standard Chinese northern rural house will be $4963.4 \mathrm{~kg}$. This amount of coal can be avoided by using the proposed solar energy system.

As a result of the combustion of fossil fuel, harmful dust and other pollutants will be diffused into the air and cause severe pollution and global warming. The air contaminants generated from the combustion of $1 \mathrm{~kg}$ of anthracite coal are shown in Table 12, and the annual contaminants for a standard Chinese northern rural house are shown in Table 13. 
solely purposed for providing corrections to the table. To preview the actual presentation of the table, please view the Proof.

The contaminants generated by per unit anthracite coal [43]

\begin{tabular}{|l|l|l|l|l|}
\hline Per unit fossil fuel & Harmful dust & $\mathbf{C O}_{2}$ & $\mathbf{S O}_{2}$ & NO$_{\mathbf{x}}$ \\
\hline Anthracite Coal $/ \mathrm{kg}$ & $0.0068 \mathrm{~kg}$ & $2.57 \mathrm{~kg}$ & $0.02 \mathrm{~kg}$ & $0.004 \mathrm{~kg}$ \\
\hline
\end{tabular}

\section{Table 13}

The annual contaminants generated by coal-driven system.

\begin{tabular}{|l|l|}
\hline Contaminants & Coal-powered(kg) \\
\hline Harmful dust & 33.7 \\
\hline $\mathrm{CO}_{2}$ & 12110.7 \\
\hline $\mathrm{SO}_{2}$ & 372.2 \\
\hline $\mathrm{NO}_{\mathrm{X}}$ & 186.1 \\
\hline
\end{tabular}

The reduction of contaminants by the solar assisted VI-ASHP system is highlighted in Table 14, on the assumption that 100 sets of the systems (e.g., to meet the demand of a village) are used. The reductions of fossil fuel consumption and pollutants are significant. In one year, the solar-based energy system could save 496.3tons of coal. During the 25-year life span of the systems, the total carbon emission savings could reach 30276.7 tons compared with the coal-based system. Furthermore, the system diminishes the emission of a lot of other harmful substances, i.e. dust, $\mathrm{SO}_{2}$ and $\mathrm{NO}_{\mathrm{x}}$, and therefore is a desirable approach to the environment sustainability.

(i) The table layout displayed in this section is not how it will appear in the final version. The representation below is solely purposed for providing corrections to the table. To preview the actual presentation of the table, please view the Proof.

fossil fuel saving and air pollutant reduction.

\begin{tabular}{|l|l|l|l|}
\hline & Contaminants & $\mathbf{2 0 1 8}$ & $\mathbf{2 5}$ years total \\
\hline Solar-based system compared with coal-based system & Mass (tons) & 496.3 & 12407.5 \\
\hline & Harmful dust (tons) & 3.4 & 84.4 \\
\hline & & \\
\hline
\end{tabular}




\begin{tabular}{|l|l|l|}
\hline $\mathrm{CO}_{2}$ (tons) & 1211 & 30276.7 \\
\hline $\mathrm{SO}_{2}$ (tons) & 37.2 & 930.6 \\
\hline $\mathrm{NO}_{\mathrm{x}}$ (tons) & 18.6 & 465.3 \\
\hline
\end{tabular}

\section{System demonstration and experimental validation}

\subsection{Mini-channel multiple-throughout-flowing solar array}

A demonstration project of the mini-channel solar-assisted air source heat pump system, which is similar to the proposed system, has been installed in a rural village of Shanxi province, as shown in Fig. 15[44]. The technical parameters of the demonstrative system are shown in Table 15. The mini-channel solar thermal panels are connected in a multiple-throughout-flowing loop as mentioned in the simulation of the proposed system. In addition, there are two solar panel arrays containing 10 and 8 panels respectively. The systems can greatly increase the thermal comfort in rural houses and significantly decrease fossil fuel consumption and environmental contaminations.

\section{Fig. 15}

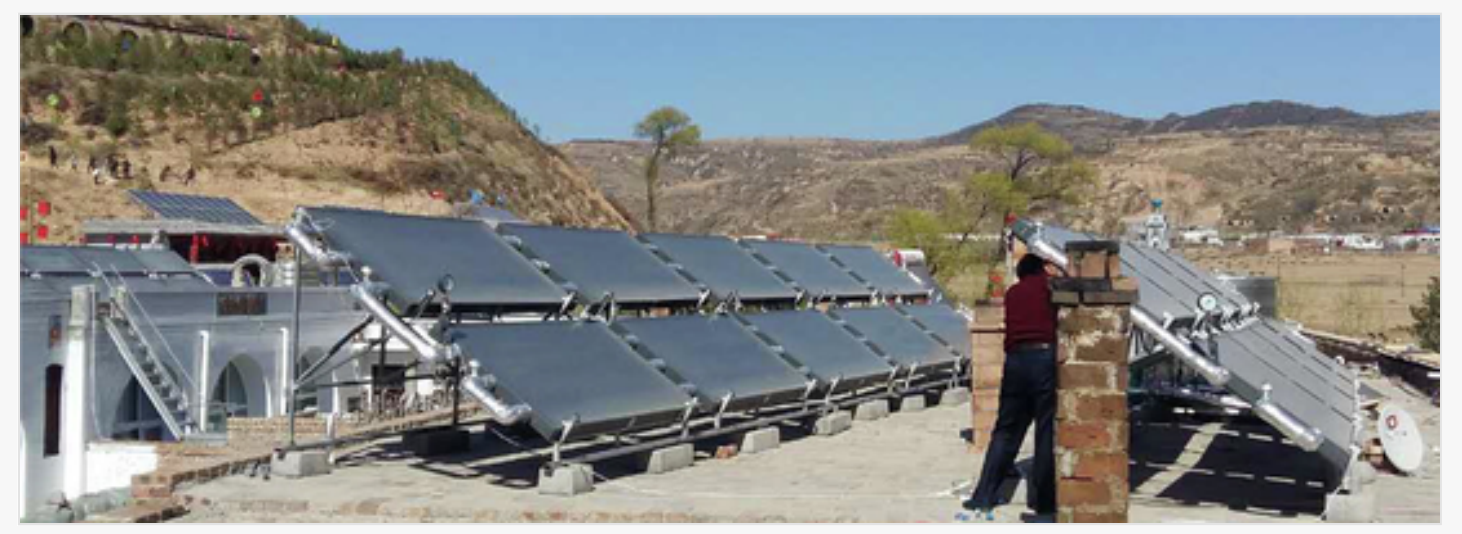

The demonstration of the solar energy systems installed at the demonstration site.

Table 15

(i) The table layout displayed in this section is not how it will appear in the final version. The representation below is solely purposed for providing corrections to the table. To preview the actual presentation of the table, please view the Proof.

Technical parameters of the system.

\begin{tabular}{|l|l|l|}
\hline Component & Size & Number \\
\hline Mini-channel solar thermal panels & $1 \mathrm{~m} * 2 \mathrm{~m}$ & 18 \\
\hline Photovoltaic panels & $1 \mathrm{~m} * 2 \mathrm{~m}$ & 4 \\
\hline Heat exchange and storage water tank & $1.5 \mathrm{t}$ & 1 \\
\hline Air source heat pump (Nominal heat supply capacity: $12 \mathrm{~kW})$ & $1.2 \mathrm{~m} * 0.5 \mathrm{~m} * 1 \mathrm{~m}$ & 1 \\
\hline
\end{tabular}


The experimental data from this demonstrative project can verify the model for the simulation of the performance of the mini-channel solar panel array. The experimental and simulated results are compared in Fig. 16 and Fig. 17. The tests were conducted on the 24th of Dec 2016. The experimental and simulative results for solar thermal efficiency and heat generation are in good agreement, within 10\% deviation, which validates the proposed model.

\section{Fig. 16}

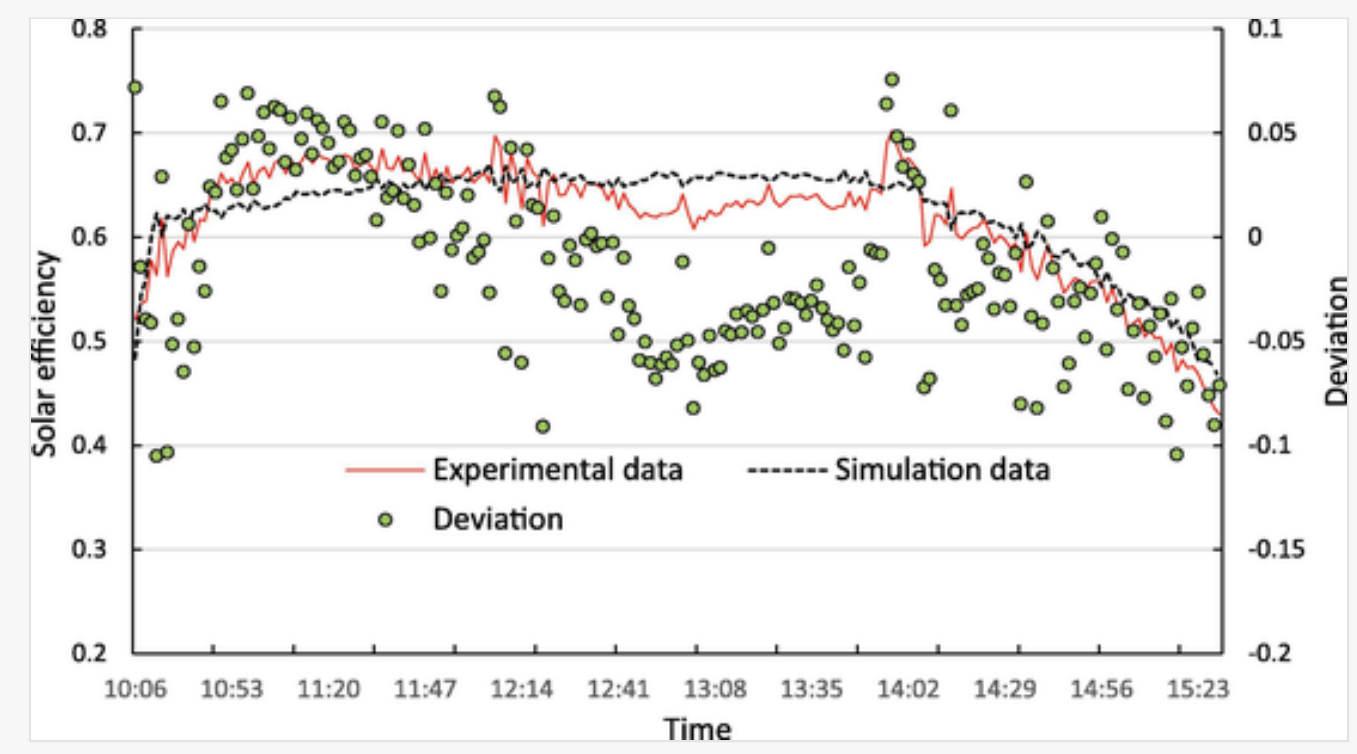

The experimental and simulative solar efficiency of the solar thermal panel arrays.

\section{Fig. 17}

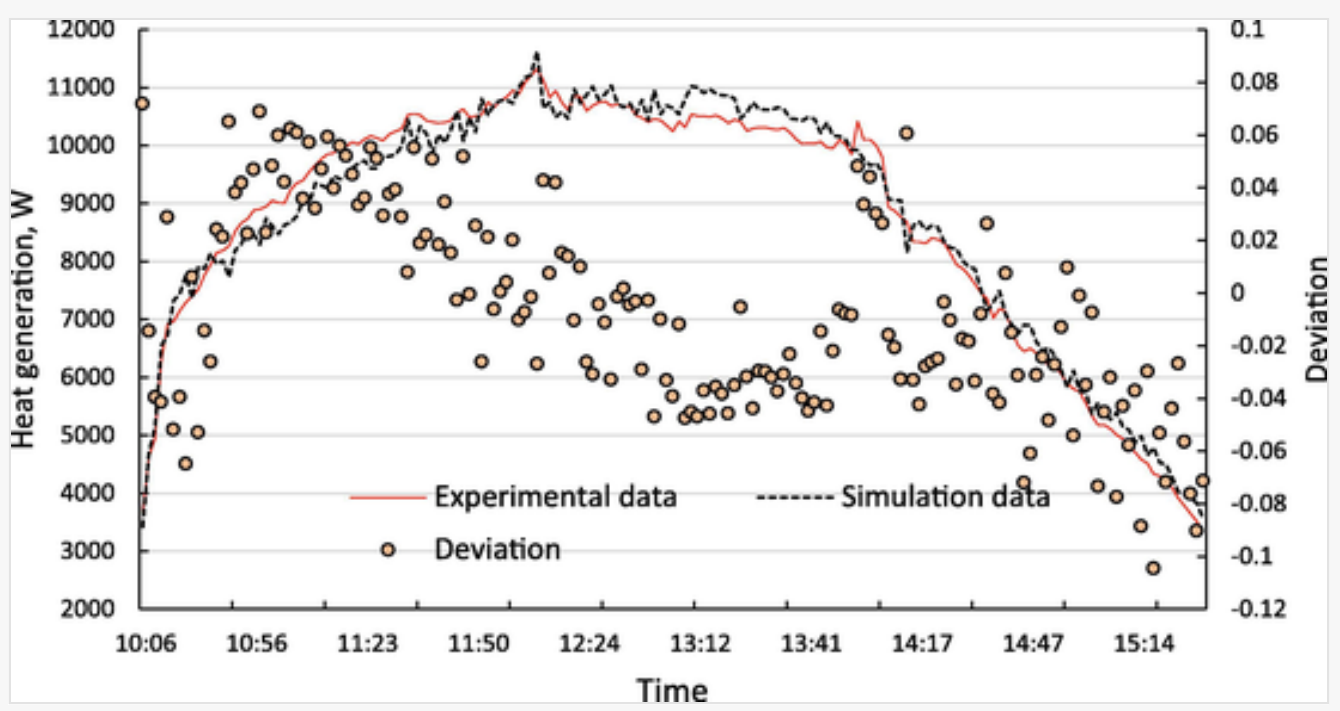

The experimental and simulative heat generation of the solar thermal panel arrays.

\subsection{VI-ASHPxxx}

To validate the mathematical model of the VI-ASHP, indoor experimental tests were conducted in a heat pump test room at Five-star Solar Energy Co. Ltd. The test room contains four key components: (1) an insulated room where the tested heat pump can be placed, as shown in Fig. 18(a); (2) an electrical power source for the whole 
system, as shown in Fig. 18(b) to provide power to the heat pump, testing room cooling devices, water pumps, control device and data collecting device; (3) an environment control device as shown in Fig. 18(c) which can collect timely temperature and humidity data from the testing room and maintain the parameters at the desired level, and the error of the controlled temperature is about within $\pm 1.5^{\circ} \mathrm{C}$; and (4) a data-collecting device as shown in Fig. 18(d) which can collect experimental data from the pre-positioned sensors, and thus calculate the heat pump performance, i.e. heat generation, electricity consumption, COP, and EER.

\section{Fig. 18}

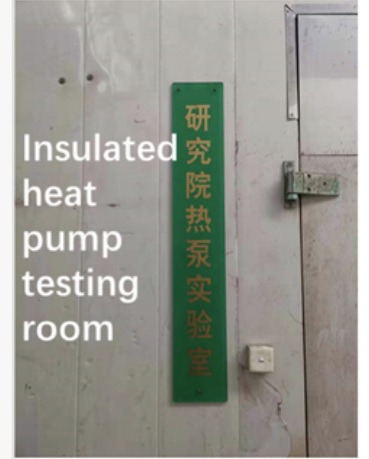

(a)

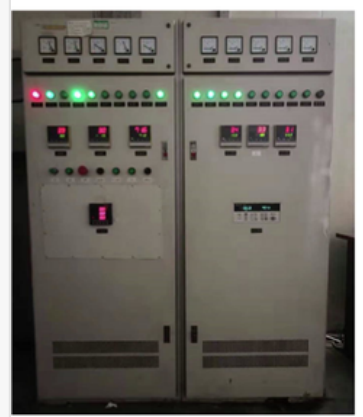

(c)

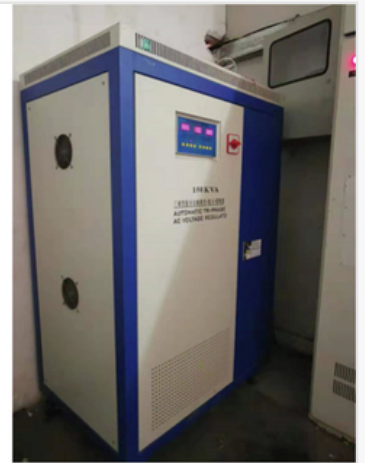

(b)

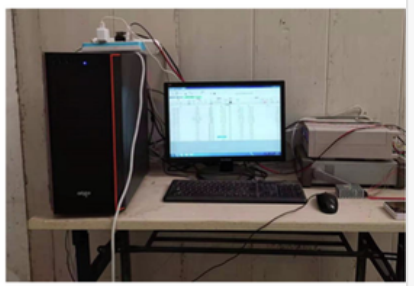

(d)

The experimental equipment of VI-ASHP (a) insulated heat pump testing room; (b) electricity power source; (c) environment control devices; (d) data collection devices.

The experimental set up for our VI-ASHP is shown in Fig. 19, whilst the technical parameters are shown in Table 16. 


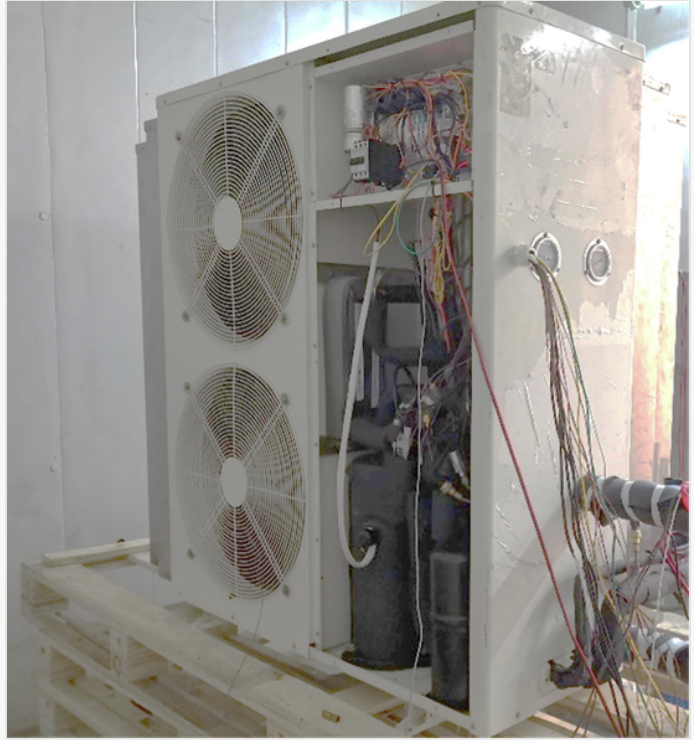

The experiment of VI-ASHP.

Table 16

(i) The table layout displayed in this section is not how it will appear in the final version. The representation below is solely purposed for providing corrections to the table. To preview the actual presentation of the table, please view the Proof.

Technical parameters of the VI-ASHP.

\begin{tabular}{|l|l|l|l|}
\hline Model & DKRS-20 & Refrigerant & R410A \\
\hline Nominal heating power $(\mathrm{kW})$ & 39 & Nominal power input (Heating, kW) & 16.18 \\
\hline Nominal cooling power $(\mathrm{kW})$ & 48 & Nominal power input (Cooling, $\mathrm{kW})$ & 17.9 \\
\hline Max current $(\mathrm{A})$ & 50 & Max power $(\mathrm{kW})$ & 27 \\
\hline Working temperature $\left({ }^{\circ} \mathrm{C}\right)$ & $-20-43$ & Rated voltage $(\mathrm{V})$ & 380 \\
\hline
\end{tabular}


The performance of the demonstrative VI-ASHP system can be simulated by using the model developed in this paper. Comparing the experimental data of the demonstrative VI-ASHP system under $-11.5^{\circ} \mathrm{C}$, the simulation results are in close agreement with the experimental results, with the deviation between results of less than $6.2 \%$ as shown in Table 17. The results fully illustrate the validity of our proposed model. VI-ASHP demonstration systems have also been built in northern China, which are shown in Fig. 20.

Table 17

Comparison between experimental and simulative performance of VI-ASHP.

\begin{tabular}{|c|c|c|c|c|c|c|c|}
\hline Ambient temperature $\left({ }^{\circ} \mathrm{C}\right)$ & -11.46 & -11.48 & -11.47 & -11.46 & -11.45 & -11.46 & -11.45 \\
\hline Power input (kW) & 13.26 & 13.24 & 13.20 & 13.19 & 13.17 & 13.19 & 13.16 \\
\hline Heat generation (kW) & 28.24 & 28.46 & 28.51 & 28.356 & 28.32 & 28.22 & 28.29 \\
\hline COP (Experiment) & 2.13 & 2.15 & 2.16 & 2.15 & 2.15 & 2.14 & 2.15 \\
\hline COP (Simulation) & 2.17 & 2.17 & 2.17 & 2.17 & 2.17 & 2.17 & 2.17 \\
\hline Deviation (\%) & 5.1 & 5.7 & 6.2 & 5.7 & 5.8 & 5.2 & 5.8 \\
\hline
\end{tabular}

\section{Fig. 20}

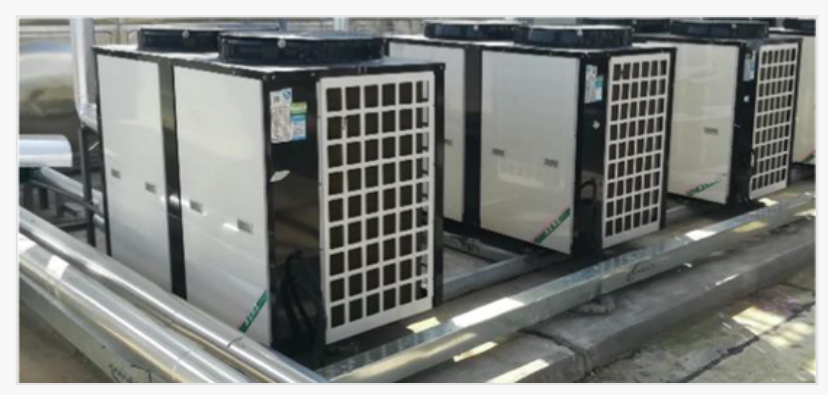

The demonstration project of VI-ASHP installed.

\section{Conclusion}

This paper proposed a dedicated economic and environmental performance study of a novel low carbon solarassisted vapour injection air source heat pump (VI-ASHP) system for space heating, cooling and domestic hot water system in cold regions. The simulation is conducted based on the weather conditions of Taiyuan, Shanxi, northern China, as this city uses coal as the main energy source to supply space heating. Consequently, the city suffers from severe air pollution and desperately needs to use renewable energy to improve the life quality and environment for local residents. The simulation results involve the prediction of fossil fuel energy savings, cost payback period on investment and life cycle carbon emission reduction of the novel system, compared to conventional coal-based heating systems. 
The mini-channel solar thermal panel array of $36 \mathrm{~m}^{2}$ and VI-ASHP of $40 \mathrm{~kW}$ have been successfully demonstrated. Experiments have been conducted and the results validate the mathematical models established in this paper. According to the analysis, the relative deviation between the established models and the experimental data is within $10 \%$, thus giving high accuracy.

The energy performances of the proposed solar-assisted VI-ASHP system and the served house are simulated and the results indicate that the heating load and cooling load for the $100 \mathrm{~m}^{2}$ served house are $17538 \mathrm{kWh}$ and $2311 \mathrm{kWh}$ respectively. The heat generated from the solar thermal panel array is $17770 \mathrm{kWh}$. To overcome this heat deficit, the VI-ASHP as a heating device is needed, which has an average COP of 3 and consumes $4394.6 \mathrm{kWh}$ of electricity during operation. The average EER of the heat pump for cooling is 6.4 whilst the annual electricity consumption for cooling is $355.2 \mathrm{kWh}$. The electricity consumed by the water pumps of the system is $1290.4 \mathrm{kWh}$. Hence, the annual total electricity consumption of the system is $6040.2 \mathrm{kWh}$ in total. The PV model can produce $216.2 \mathrm{kWh} / \mathrm{m}^{2}$ annually. With $4 \times 2 \mathrm{~m}^{2} \mathrm{PV}$ panels, the yearly electricity generation by solar energy is $1729.6 \mathrm{kWh}$. According to the feed-in tariff of $0.75 \mathrm{RMB} / \mathrm{kWh}$ in Shanxi, the served house can earn 1297.2RMB per year by transferring the generated electricity to the power grid. Equally, with this amount of earned money, the PV module can provide $1633 \mathrm{kWh}$ electricity to the system. The energy contribution by solar thermal energy, photovoltaic energy and electricity from the power grid is $74.6 \%$, $6.9 \%$ and $18.5 \%$ respectively.

In regard to the economic performance, the initial capital cost of the novel solar heat pump system is 30290RMB, in which the most expensive component is the VI-ASHP accounting for nearly $34 \%$ of the total cost. Due to lower operational costs compared with the conventional coal-based system, the novel system has a cost payback period of around 6.52 years and a life-cycle net cost saving of nearly 56328.4RMB in Shanxi, thereby indicating the system is economically viable.

The proposed system is also environmentally friendly. While a conventional coal-based system for a standard rural house in northern China may use 5tons of anthracite coal each year and generate $33.7 \mathrm{~kg}$ of harmful dust, 12.1tons of $\mathrm{CO}_{2}, 372.2 \mathrm{~kg}$ of $\mathrm{SO}_{2}$ and $186.1 \mathrm{~kg}$ of $\mathrm{NO}_{\mathrm{x}}$, the solar-assisted VI-ASHP system can operate without contaminant emission and save the above amount of anthracite coal by employing solar and electrical energy. Based on the performance of the demonstration system, it is anticipated that a village of 100 sets of installed capacity will save 496.3 tons of coal per year. During the 25 -year life span, the total carbon emission reduction is 30276.7 tons.

In summary, the novel solar-assisted VI-ASHP system can significantly improve energy efficiency and reduce the energy consumption for space heating, cooling, and hot water supply. It is a promising approach to near-zero carbon emission from buildings. Although the system is demonstrated in northern China, it is expected to be applicable in other cold regions of the world.

\section{CRediT authorship contribution statement}

Yi Fan: Investigation, Methodology, Formal analysis, Writing - original draft. Xudong Zhao: Supervision, Conceptualization, Funding acquisition. Jing Li: Supervision, Conceptualization, Project administration. Guiqiang Li: Resources. Steve Myers: Writing - review \& editing. Yuanda Cheng: Software. Ali Badiei: Writing - review \& editing. Min Yu: Data curation. Yousef Golizadeh Akhlaghi: Resources. Samson Shittu: Validation. Xiaoli Ma: Writing - review \& editing. 
The authors declare that they have no known competing financial interests or personal relationships that could have appeared to influence the work reported in this paper.

\section{Acknowledgment}

The authors would like to acknowledge our appreciation for the financial support received from the following projects: 'A low carbon heating system for existing public buildings employing a highly innovative multiplethroughout-flowing micro-channel solar-panel-array and a novel mixed indoor/outdoor air source heat pump' funded by the UK BEIS.

\section{References}

The corrections made in this section will be reviewed and approved by a journal production editor. The newly added/removed references and its citations will be reordered and rearranged by the production team.

[1] Evans M., Yu S., Song B., Deng Q., Liu J., Delgado A. Building energy efficiency in rural China. Energy Policy 2014;64:243-251. doi:10.1016/j.enpol.2013.06.040.

[2] Zhu Saihong Su. Shan L shuang. The strategy of rural residential thermal environment adjustment in cold areas (in Chinese). Art Technol 2016;29:306-307.

[3] Shan M., Wang P., Li J., Yue G., Yang X. Energy and environment in Chinese rural buildings: Situations, challenges, and intervention strategies. Build Environ 2015;91:271-282. doi:10.1016/j.buildenv.2015.03.016.

[4] Zhang X., Zhao X., Shen J., Hu X., Liu X., Xu J. Design, fabrication and experimental study of a solar photovoltaic/loop-heat-pipe based heat pump system. Sol Energy 2013;97:551-568. doi:10.1016/j.solener.2013.09.022.

[5] Diao Y.H., Wang S., Zhao Y.H., Zhu T.T., Li C.Z., Li F.F. Experimental study of the heat transfer characteristics of a new-type flat micro-heat pipe thermal storage unit. Appl Therm Eng 2015;89:871-882. doi:10.1016/j.applthermaleng.2015.06.070.

[6] Tosun M., Doğan B., Öztürk M.M., Erbay L.B. Integration of a mini-channel condenser into a household refrigerator with regard to accurate capillary tube length and refrigerant amount. Int J Refrig 2019;98:428-435. doi:10.1016/j.ijrefrig.2018.11.012.

[7] Li G., Diallo T.M.O., Akhlaghi Y.G., Shittu S., Zhao X., Ma X., et al. Simulation and experiment on thermal performance of a micro-channel heat pipe under different evaporator temperatures and tilt angles. Energy 2019;179:549-557. doi:10.1016/j.energy.2019.05.040.

[8] Deng Y., Wang W., Zhao Y., Yao L., Wang X. Experimental study of the performance for a novel kind of MHPA-FPC solar water heater. Appl Energy 2013;112:719-726. doi:10.1016/j.apenergy.2013.06.019.

[9] Fan Y., Zhao X., Li G., Cheng Y., Zhou J., Yu M., et al. Analytical and experimental study of an innovative multiple-throughout-flowing micro-channel-panels-array for a solar-powered rural house space heating system. Energy 2019;171:566-580. doi:10.1016/j.energy.2019.01.049. 
[10] Sateikis I., Lynikiene S., Kavolelis B. Analysis of feasibility on heating single family houses in rural areas by using sun and wind energy. Energy Build 2006;38:695-700. doi:10.1016/j.enbuild.2005.11.003.

[11] Huang J., Fan J., Furbo S. Feasibility study on solar district heating in China. Renew Sustain Energy Rev 2019;108:53-64. doi:10.1016/j.rser.2019.03.014.

[12] Chen X., Qi C. Nonlinear neighbor embedding for single image super-resolution via kernel mapping. Signal Process 2014;94:6-22. doi:10.1016/j.sigpro.2013.06.016.

[13] Gong G., Tang J., Lv D., Wang H. Research on frost formation in air source heat pump at coldmoist conditions in central-south China. Appl Energy 2013;102:571-581. doi:10.1016/j.apenergy.2012.08.001.

[14] Yao Y., Jiang Y., Deng S., Ma Z. A study on the performance of the airside heat exchanger under frosting in an air source heat pump water heater/chiller unit. Int J Heat Mass Transf 2004;47:37453756. doi:10.1016/j.ijheatmasstransfer.2004.03.013.

[15] Hakkaki-Fard A., Aidoun Z., Ouzzane M. Improving cold climate air-source heat pump performance with refrigerant mixtures. Appl Therm Eng 2015;78:695-703. doi:10.1016/j.applthermaleng.2014.11.036.

[16] Shao S., Zhang H., You S., Zheng W., Jiang L. Thermal performance analysis of a new refrigerant-heated radiator coupled with air-source heat pump heating system. Appl Energy 2019;247:78-88. doi:10.1016/j.apenergy.2019.04.032.

[17] Wang X., Hwang Y., Radermacher R. Two-stage heat pump system with vapor-injected scroll compressor using R410A as a refrigerant. Int $J$ Refrig 2009;32:1442-1451. doi:10.1016/j.ijrefrig.2009.03.004.

[18] Wang W., Li Y. Intermediate pressure optimization for two-stage air-source heat pump with flash tank cycle vapor injection via extremum seeking. Appl Energy 2019;238:612-626. doi:10.1016/j.apenergy.2019.01.083.

[19] Xu X., Hwang Y., Radermacher R. Refrigerant injection for heat pumping/air conditioning systems: Literature review and challenges discussions. Int J Refrig 2011;34:402-415. doi:10.1016/j.ijrefrig.2010.09.015.

[20] Cho H., Baek C., Park C., Kim Y. Performance evaluation of a two-stage CO2 cycle with gas injection in the cooling mode operation. Int J Refrig 2009;32:40-46. doi:10.1016/j.ijrefrig.2008.07.008.

[21] Dutta A.K., Yanagisawa T., Fukuta M. An investigation of the performance of a scroll compressor under liquid refrigerant injection. Int $\mathrm{J}$ Refrig 2001;24:577-587. doi:10.1016/S01407007(00)00041-4.

[22] Fernández-Hernández Francisco, Fernández-Gutiérrez Alberto, Martínez-Almansa Juan José, del Pino C., Parras L. Flow patterns and heat transfer coefficients using a rotational diffuser coupled 
with a radiant floor cooling. Appl Therm Eng 2020;168:114827. doi:10.1016/j.applthermaleng.2019.114827.

[23] Athienitis A.K., Chen T.Y. Experimental and theoretical investigation of floor heating with thermal storage. ASHRAE Trans 1993;99:1049-1057.

[24] Karimi M.S., Fazelpour F., Rosen M.A., Shams M. Comparative study of solar-powered underfloor heating system performance in distinctive climates. Renew Energy 2019;130:524-535. doi:10.1016/j.renene.2018.06.074.

[25] Inard C., Meslem A., Depecker P. Energy consumption and thermal comfort in dwelling-cells: A zonal-model approach. Build Environ 1998;33:279-291. doi:10.1016/S0360-1323(97)00074-7.

[26] Karakoyun Yakup, Acikgoz Ozgen, Yumurtac1 Zehra, Dalkilic Ahmet Selim An experimental investigation on heat transfer characteristics arising over an underfloor cooling system exposed to different radiant heating loads through walls. Appl Therm Eng 2020;164:114517. doi:10.1016/j.applthermaleng.2019.114517.

[27] Chen J., Yu J. Energy and exergy analysis of a new direct-expansion solar assisted vapor injection heat pump cycle with subcooler for water heater. Sol Energy 2018;171:613-620. doi:10.1016/j.solener.2018.07.019.

[28] Lu S., Liang R., Zhang J., Zhou C. Performance improvement of solar photovoltaic/thermal heat pump system in winter by employing vapor injection cycle. Appl Therm Eng 2019;155:135-146. doi:10.1016/j.applthermaleng.2019.03.038.

[29] CHN_Shanxi.Taiyuan. 537720_CSWD. Weather Data n.d. https://energyplus.net/.

[30] Xudong Z., Xiaoli M. Advanced Energy Efficiency Technologies for Solar Heating. Cooling and Power Generation: Springer; 2019.

[31] Zhou J., Zhao X., Ma X., Du Z., Fan Y., Cheng Y., et al. Clear-days operational performance of a hybrid experimental space heating system employing the novel mini-channel solar thermal \& PV/T panels and a heat pump. Sol Energy 2017;155:464-477. doi:10.1016/j.solener.2017.06.056.

[32] Cho I.Y., Seo H.J., Kim D., Kim Y. Performance comparison between R410A and R32 multi-heat pumps with a sub-cooler vapor injection in the heating and cooling modes. Energy 2016;112:179187. doi:10.1016/j.energy.2016.06.069.

[33] The compressor products brochure provided by Emerson Electric Co. n.d. https://climate.emerson.com/documents/谷轮涡旋-zW 系列热泉专用压缩机产品手册-zWcompressor-catalogue-zh-cn-5407826.pdf.

[34] Hans L., Fritz S. Heat Pump Technology. Butterworth-Heinemann; 1981.

[35] Bell D.A., Towler B.F., Fan M., Bell D.A., Towler B.F., Fan M. The Nature of Coal. Coal Gasif. Its Appl., William Andrew Publishing 2011;1-15. doi:10.1016/B978-0-8155-2049-8.10001-4.

[36] Zhang Q., Yi H., Yu Z., Gao J., Wang X., Lin H., et al. Energy-exergy analysis and energy efficiency improvement of coal-fired industrial boilers based on thermal test data. Appl Therm Eng 
2018;144:614-627. doi:10.1016/j.applthermaleng.2018.08.069.

[37] Zhang X., Shen J., Xu P., Zhao X., Xu Y. Socio-economic performance of a novel solar photovoltaic/loop-heat-pipe heat pump water heating system in three different climatic regions. Appl Energy 2014;135:20-34. doi:10.1016/j.apenergy.2014.08.074.

[38] The feed-in tariff price for $\quad$ PV $\quad$ panel 2018. http://www.ndrc.gov.cn/xwzx/xwfb/201712/t20171222_871333.html.

[39] Nottingham T, User NE. Wang, Zhangyuan (2012) Investigation of a novel façade-based solar loop heat pipe water heating system . PhD thesis, University of Nottingham . Investigation of a Novel Façade-Based Solar Loop Heat Pipe Water Heating System. 2012.

[40] Kannan R., Leong K.C., Osman R., Ho H.K., Tso C.P. Life cycle assessment study of solar PV systems: An example of a $2.7 \mathrm{kWp}$ distributed solar PV system in Singapore. Sol Energy 2006;80:555-563. doi:10.1016/j.solener.2005.04.008.

[41] Taiyuan electricity price 2018. http://www.sdfcxw.com/dianfei/lvliang.html.

[42] Anthracite coal price 2018. https://coalpail.com/coal-forum/viewtopic.php?f=112\&t=50084.

[43] The contaminants generated by per unit anthracite coal n.d. https://www3.epa.gov/ttn/chief/ap42/ch01/final/c01s02.pdf.

[44] The development of 100 sets of the novel solar-powered systems 2017. http://www.sxrtv.com/content/v/a/2017-2-6/1486379276435.shtml? from $=$ timeline\&isappinstalled $=0$.

\section{Highlights}

- First time that mini-channel panels are combined with vapor injection heat pump.

- Both heating and cooling performances throughout the year are estimated.

- Technology demonstration with panels of $36 \mathrm{~m}^{2}$ and heat pump of $40 \mathrm{~kW}$ has been done.

- The payback time of the novel system is about 6.52 years.

- The annual carbon emission is reduced by 12.1 tons for a rural house in northern China.

\section{Queries and Answers}

Query: Your article is registered as belonging to the Special Issue/Collection entitled "ICAE2019". If this is NOT correct and your article is a regular item or belongs to a different Special Issue please contact j.ramkumar@elsevier.com immediately prior to returning your corrections. 
Query: Please note that as per standard style, a corresponding author footnote be provided for at least one author. Please check and assign the corresponding author name and also provide a professional email for the author. Answer: *Corresponding author (Xudong Zhao）. Tel.: +44-01482466684, Email: xudong.zhao@hull.ac.uk ** Corresponding author (Jing Li). Tel.: +44-01482463611, Email: jing.li@hull.ac.uk

Query: The author names have been tagged as given names and surnames (surnames are highlighted in teal color). Please confirm if they have been identified correctly.

Answer: Yes

Query: Have we correctly interpreted the following funding source(s) and country names you cited in your article: BEIS, United Kingdom? /

Answer: Yes 